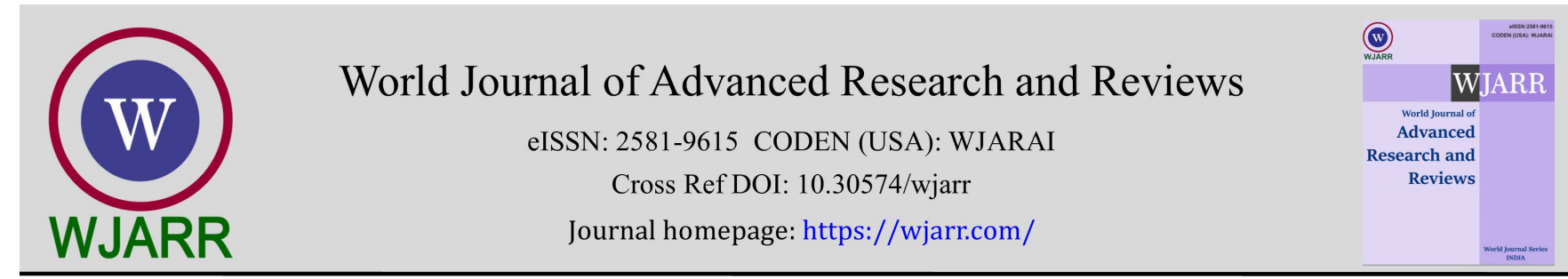

(REVIEW ARTICLE)

Check for updates

\title{
Catalogue of Some Saltwater and Freshwater Fish Species of the Niger Delta Region of Nigeria
}

\author{
Ekinadose Orose, Edafe Odioko and Okechukwu Kenneth Wokeh* \\ Department of Animal and Environmental Biology, Hydrobiology and Fisheries Unit, University of Port Harcourt, PMB \\ 5323, Port Harcourt, Rivers State, Nigeria.
}

World Journal of Advanced Research and Reviews, 2021, 09(03), 056-084

Publication history: Received on 29 January 2021; revised on 27 February 2021; accepted on 01 March 2021

Article DOI: https://doi.org/10.30574/wjarr.2021.9.3.0075

\begin{abstract}
The study was done to review some saltwater and freshwater fish species in the Niger Delta region of Nigeria. The Niger Delta is one of the most prominent regions in Nigeria, endowed with several water bodies that are distributed as freshwater like rivers, lakes, streams and creeks. These freshwater ecosystems in the region, are abundantly endowed with fish species such as Clarias gariepinus, Pila ovate, Labeo coubie, Synodontis budgetti and Synodontis eupterus. Apart from the freshwaters, the region also has vast marine ecosystem with abundance of fish species such as Elops lacerta, Mugil cephalus, Thais coronata, Periophthalmus papilio, Tympanotonus fuscatus, and Sardinella maderensis. Unfortunately, many of these fish species are endangered due to constant pollution in the Niger delta regional coastal environment. As a result, it is important to document some available freshwater and marine water fish species which will serve as a reference material for both academics and research institutions, should any of the fish species go into extinction.
\end{abstract}

Keywords: Extinction, Coastal Waters, Marine Diversity, Niger Delta

\section{Introduction}

Nigeria's coastal waters fall within the Guinea Current Large Ecosystem (GCLME), a shared resource by all the coastal West African countries. The Nigeria coastal area is one of the world's most productive marine ecosystems with the following attributes:

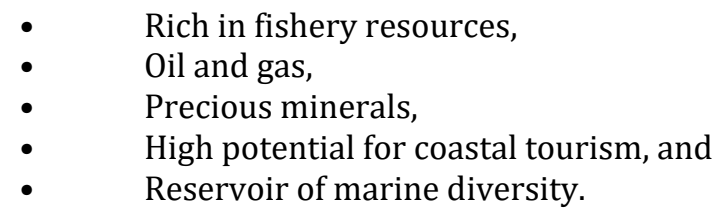

The Niger Delta which is located on the Atlantic coast of Southern Nigeria and make up majority of the Nigerian coastal area, lies within the lower reaches of the Niger river, extending between latitudes $05^{\circ} 19^{\prime} 34^{\prime \prime} \mathrm{N} 06^{\circ} 28^{\prime} 15^{\prime \prime} \mathrm{E}$ and $\left.5.32611^{\circ} \mathrm{N} 6.47083^{\circ} \mathrm{E}[1,2]\right)$. The average monthly temperature of the region is $27^{\circ} \mathrm{C}$, and an annual rainfall ranging from 3000 to $4500 \mathrm{~mm}$. There are two distinct seasons with the wet season occurring from July to September and the dry season from December to February [3]. The Delta is among the 10 largest in the world, with a coastline of about 450 $\mathrm{km}$ which ends at Imo river entrance. The region encompasses an area of 20,000 km2 and is the largest delta in Africa and the third largest in the world $[2,4,5]$.

\footnotetext{
* Corresponding author: Wokeh Okechukwu Kenneth; Email: wokehokechukwu@gmail.com

Department of Animal and Environmental Biology, Hydrobiology and Fisheries Biology University of Port Harcourt, Port Harcourt, Rivers State, Nigeria.

Copyright (C) 2021 Author(s) retain the copyright of this article. This article is published under the terms of the Creative Commons Attribution Liscense 4.0.
} 
The Niger Delta region is one of the most prominent regions in Nigeria, endowed with several water bodies that are distributed as freshwater like rivers, stream, creeks, lakes and estuaries (which interphase fresh and salt water) and marine water [6]. The region is made of nine states, viz: Abia, Akwa Ibom, Bayelsa, Cross River, Delta, Edo, Imo, Ondo and Rivers states (figure 1). The region covers approximately 2370 Square kilometers of mainly flowing fresh waters and 8600 square $\mathrm{km}$ of stagnant swamps $[7,2,6]$.

The Niger Delta aquatic ecosystem is greatly blessed with variety of fish species, both fin and shellfishes. Many of the fish species are endangered due to constant pollution of the Niger Delta regional coastal environment by the petroleum and allied industries. Due to the danger faced by the fish species in the Niger Delta region, a catalogue that will serve as a reference material both for the present and future generation in case some of the species present today go into extinction is needed. It is against this backdrop, we dim it vital to present some available fishes in both fresh and marine waters in the Niger Delta region due to paucity of information on this area of fisheries, which will serve as baseline information to students, teachers, researchers and regulatory agencies.

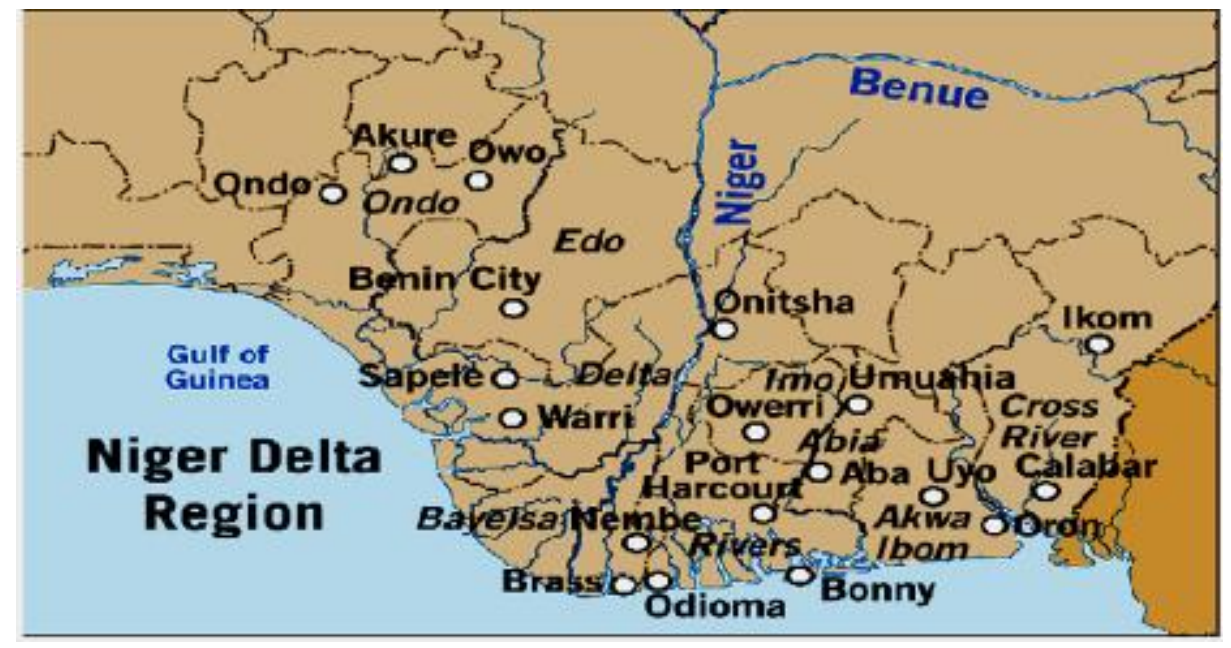

Figure 1: The Niger Delta Region of Nigeria [8].

\subsection{Some Saltwater Species of the Niger Delta Region of Nigeria}

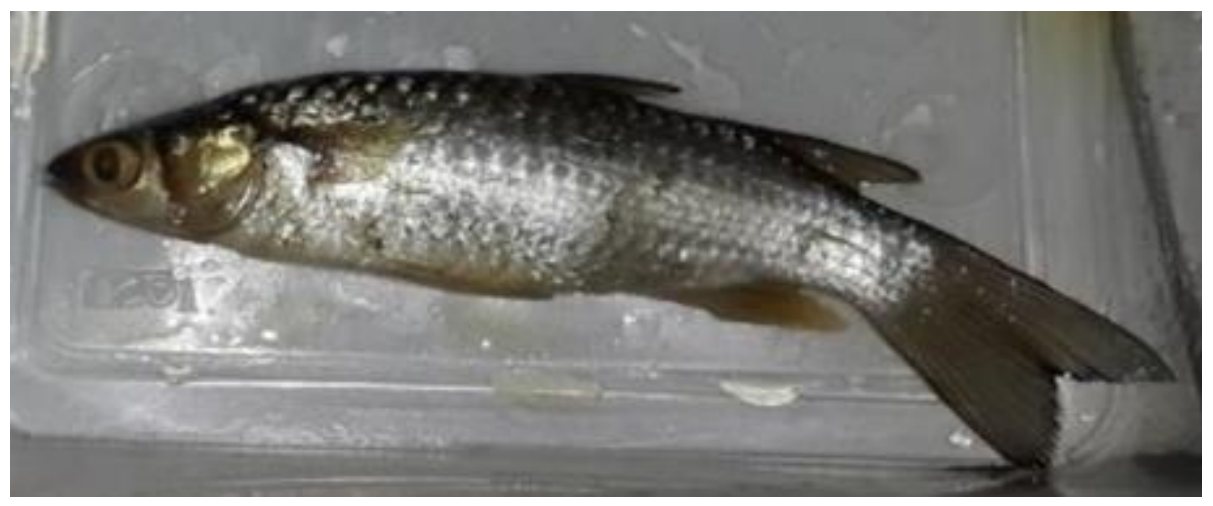

Family: Elopidae

\subsubsection{Scientific name: Elops lacerta (West African Ladyfish)}

Zoogeography: It is native to the coastal waters of the eastern Atlantic Ocean, from Senegal to Angola or Namibia. Sometimes entering freshwater, like in Cross Rivers and Kouilon-Niari.

Habitat Preference: Leave in shallow coastal waters with sandy-muddy substrates.

Food and Feeding Habit: Feeds on fish and shrimps (Carnivorous)

Reproduction: Spawn at sea, oviparous. 
Distinguishing Features and Morphology: No dorsal spines, Anal spines, lateral line scales ornamented with nonramified small tubes. Gray back, silver glossy sides fins tinted yellow.

Economic Importance: For food and commercial

Conservation Status: Least Concern (LC)

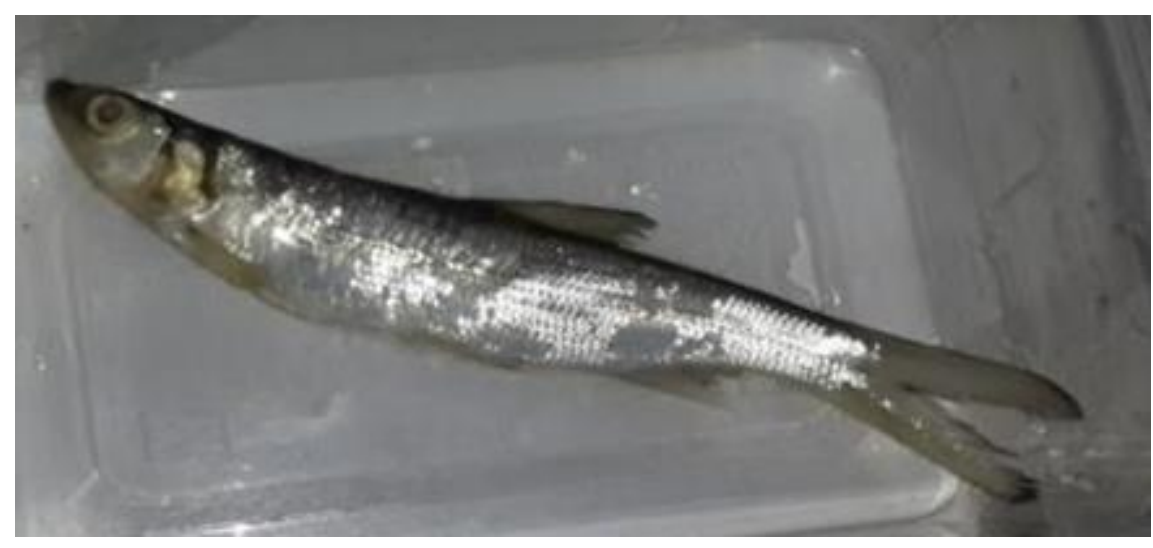

Family: Mugildae

\subsubsection{Scientific Name: Mugil cephalus (Mullet)}

Zoogeography: Occurs in the coastal waters of the tropical and subtropical zones of all seas.

Habitat Preference: Inhabit sandy and muddy bottoms of wasted waters and estuaries, sometimes found in freshwater.

Food and Feeding Habit: Feeds on Fish and Benthic Crustaceans as well as on Mollusks and Worms (Carnivorous).

Reproduction: They are Oviparous.

Distinguishing Features and Morphology: Maximum length of mullet is $120 \mathrm{~cm}$, the body of striped mullet is subcylindrical and anteriorly compressed. They have a small terminal mouth with inconspicuous teeth and a blunt nose.

Economic Importance: They are commercial fishery

Conservation Status: Conserved

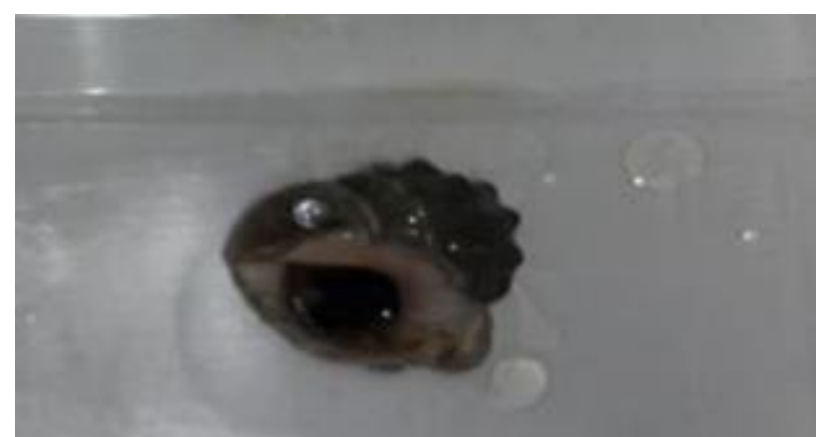

Family: Muricidae

\subsubsection{Scientific Name: Thais coronata (Abalone)}

Zoogeography: They are found on the seashore in the littoral and sub-littoral zone in all parts of the world. In the Baltic, they live within the influence of freshwater and frequently become distorted in consequence.

Habitat: Coastal, Estuarine Benthic Dwellers. 
Food and Feeding Habits: They are omnivorous (meaning they eat both plants and animals).

Reproduction: They are Oviparous during the spring tide.

Distinguishing Features and Morphology: The thick, pointed shell is turbinated and has few whorls. The aperture is rounded. The outer lip is acute.

Economic Importance: Commercial fishery

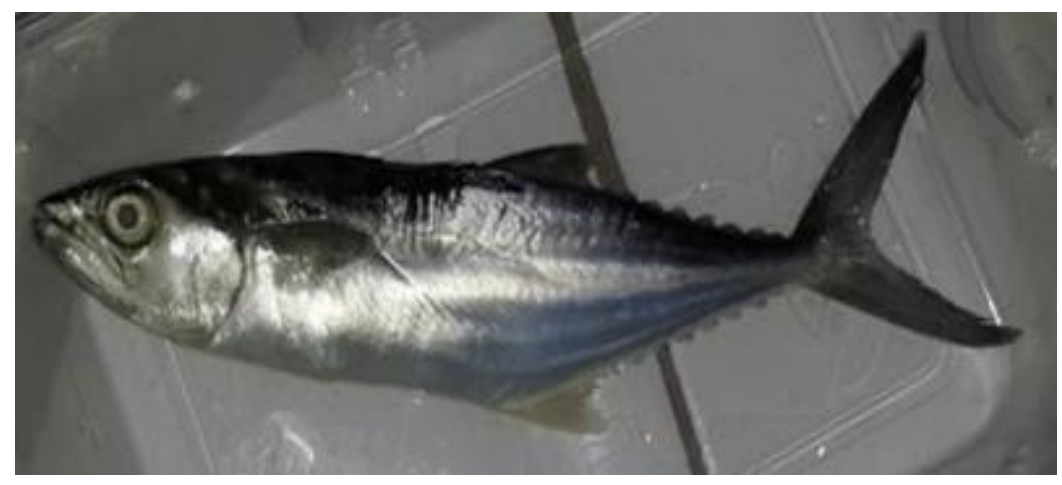

Family: Scombridae

\subsubsection{Scientific name: Cybium tritor (West African Spanish Mackerel)}

Zoogeography: This species is present in the eastern Atlantic from the Canary, Islands and Senegal south through the Gulf of Guinea to Baia dos Tigres, in Southern Angola. It is rarely found in the northern Mediterranean Sea, along the coasts of France and Italy.

Habitat Preference: This is a pelagic, oceanodromous species that inhabits warm waters.

Food and Feeding Habit: Crustaceans, Small Fish - Carnivorous

Reproduction: Oviparous migrant spawner

Economic Importance: Commercial Purpose.

Conservation Status: Red-list by IUCN.

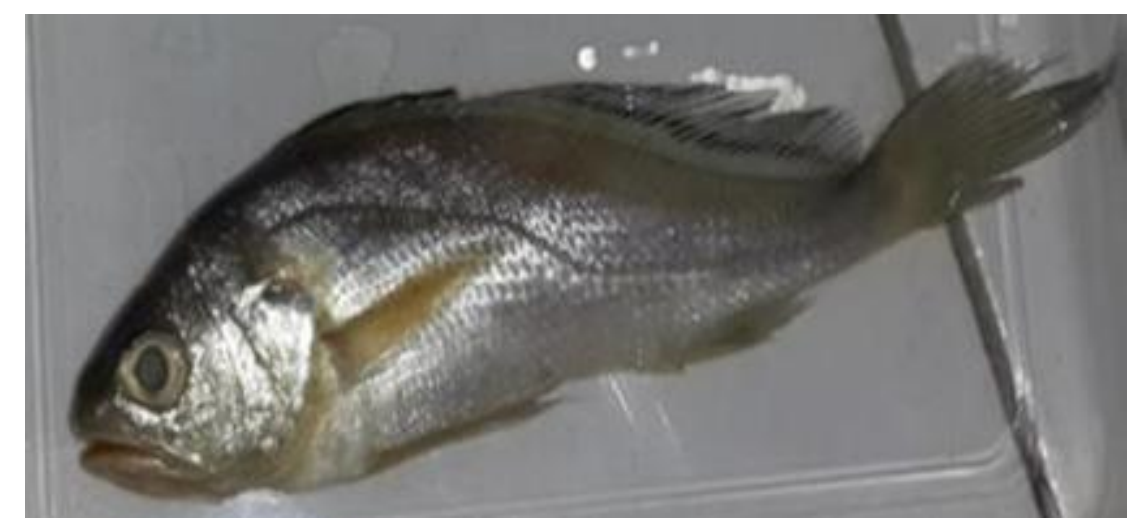

Family: Sciaenidae 


\subsubsection{Scientific name: Pseudotolitus elongatus (Croaker)}

Zoogeography: They are primarily marine, but are also found mostly seasonally in brackish waters over sandy or muddy bottoms in coastal area with large river run-offs

Habitat Preference: Sandy and muddy bottoms in coastal areas with large river run-offs.

Food and Feeding Habit: Chiefly on shrimps and other small crustaceans, detritivore and carnivore.

Reproduction: Oviparous and lay many small demersal eggs on gravel bottoms.

Distinguishing Features: The body is distinctively elongated and slightly compressed. Eyes are large, head short and lateral line are extended to the tip of caudal fin.

Economic Importance: Commercial, game fish.

Conservation Status: Not Evaluated.

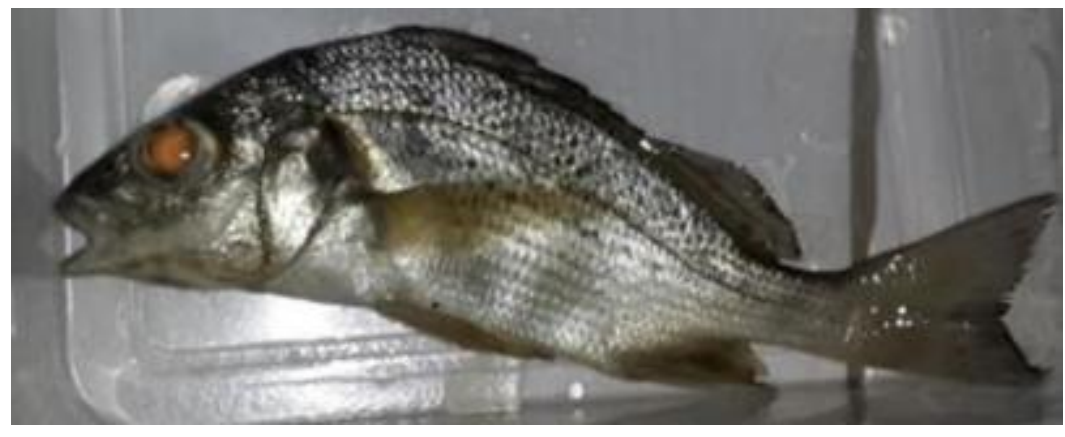

Family: Haemulidae

\subsubsection{Scientific name:Pomadasys perotaei (Grunter)}

Zoogeography: Tropical, Eastern Atlantic: Mauritania to Angola and through the Indian Ocean to the Pacific coast of the Americas.

Habitat Preference: Brackish; benthopelagic; depth range 100-250m.

Food and Feeding Habit: Feeds on other fish, shrimps, crabs, mollusks, annelids, zooplankton and detritus.

Distinguishing Features: Dorsal spines 11-13, dorsal soft rays, 15-16, anal spines, 3, anal soft rays 10.

Economic Importance: For food

Conservation Status: IUCN Red list status 


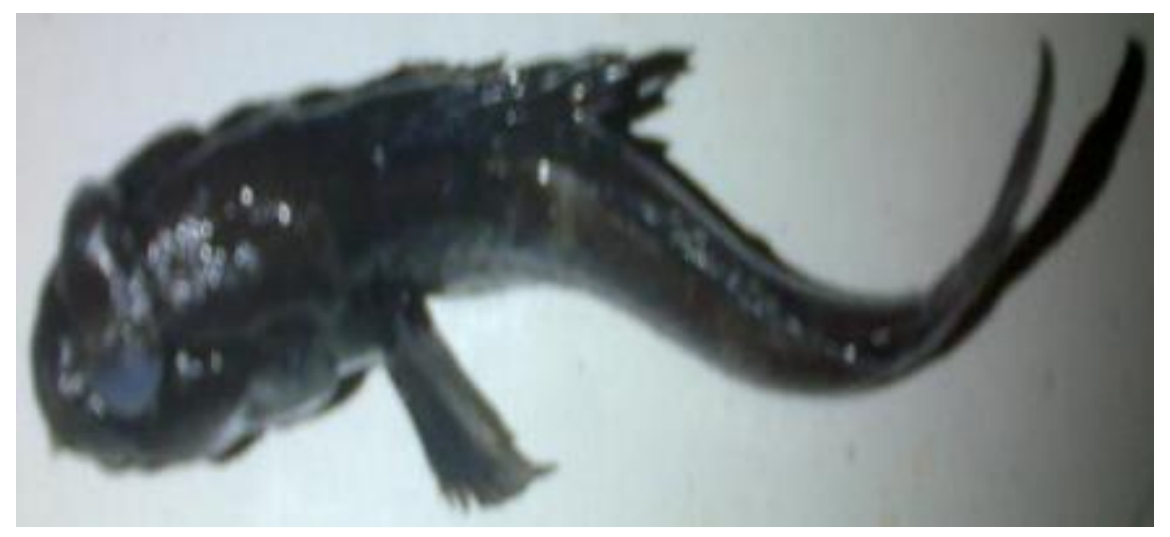

Family: Periophthalmidae

\subsubsection{Scientific name: Periophthalmus papilio (Mudskipper)}

Zoogeography: Tropical Atlantic coasts of Africa, including most offshore islands, through the Indian Ocean and into the western Pacific Ocean

Habitat Preference: It is littoral and amphibious in mudflats of estuaries and mangrove swamps.

Food and Feeding Habit: Feeds on arthropods (insects, crabs etc.) on mud surface that is they are carnivorous.

Reproduction: They are oviparous.

Distinguishing Features: The body is compressed and tapering, while the head is rounded with a sub-terminal mouth. The stalked dorsally located eye, which may be elevated or retracted are well developed for air vision, close together and there is a lower eyelid fold.

Economic Importance: It is used as bait for catching bigger fishes and it is also a good source of food fish.

Conservation Status: Least Concern (LC).

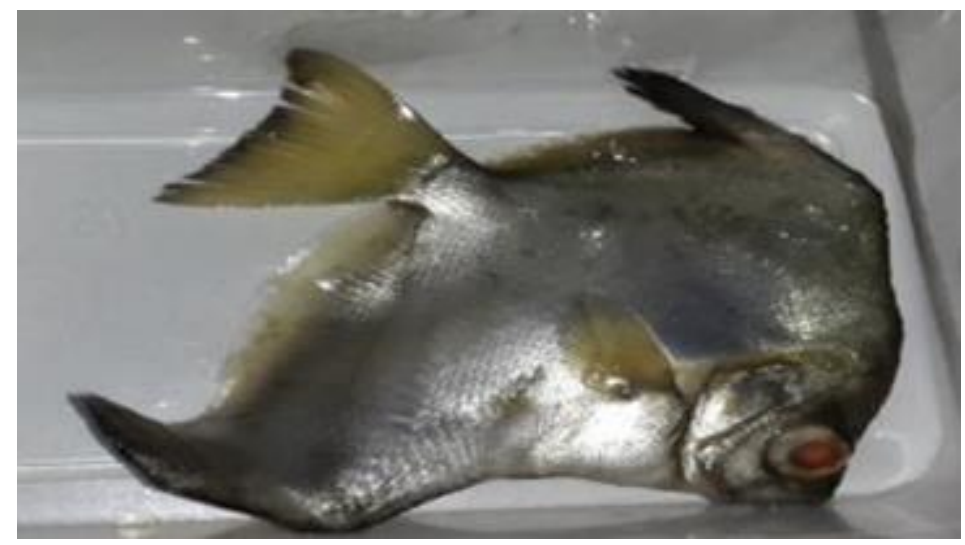

Family: Monodactylidae

1.1.8. Scientific name: Monodactylus sebae (Angel-fish, Seba Mono).

Zoogeography: West Africa, Canary Islands and Senegal to Angola.

Habitat: Mainly estuaries and mangroves.

Food and Feeding Habit: Small fish, insect larvae, pellets, peas, lettuce, plant debris (Omnivorous). 
Reproduction: Spawning immediately follows a simple courtship where the male circles the female, about 4,000 eggs are laid, which hatch in 24-60hours.

Distinguishing Features and Morphology: A tall, disc-shaped fish with lateral compression. The head is small, as well as the mouth. The eyes are large and have a black band running throw them; the body is silver to white in colour.

Economic Importance: Food and Commercial

Conservation Status: IUCN-Threatened species.

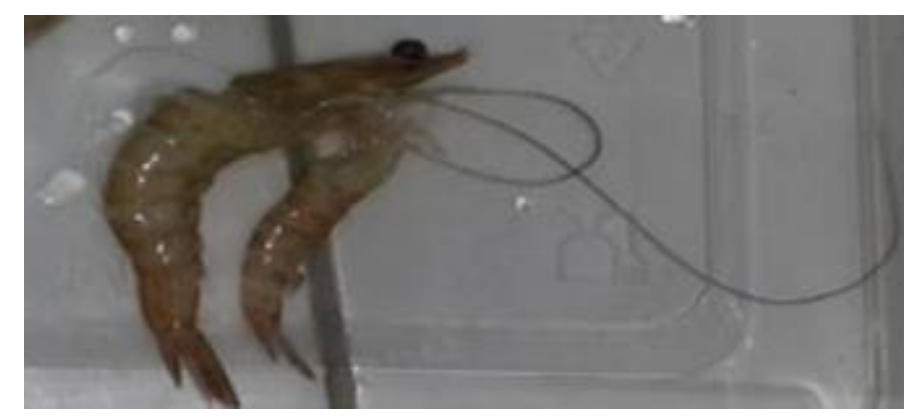

Family: Penaeidae

\subsubsection{Scientific name: Penaeous notialis (Brown Shrimp)}

Zoogeography: Eastern Altantic: West African coast from Mauritania to Angola. Western Atlantic: Greater Antilles from Cuba to the Virgin Islands; Atlantic coast of Middle and South America from S. Mexico to Brazil

Habitat Preference: Estuarine biome and usually patches among rocks. Marine; juvenile estuarine.

Food and Feeding Habit: Detritus debris, fragment of many different animals, they are omnivorous.

Reproduction: Oviparous.

Economic importance; It is an abundant species and important to commercial fisheries throughout its ranges.

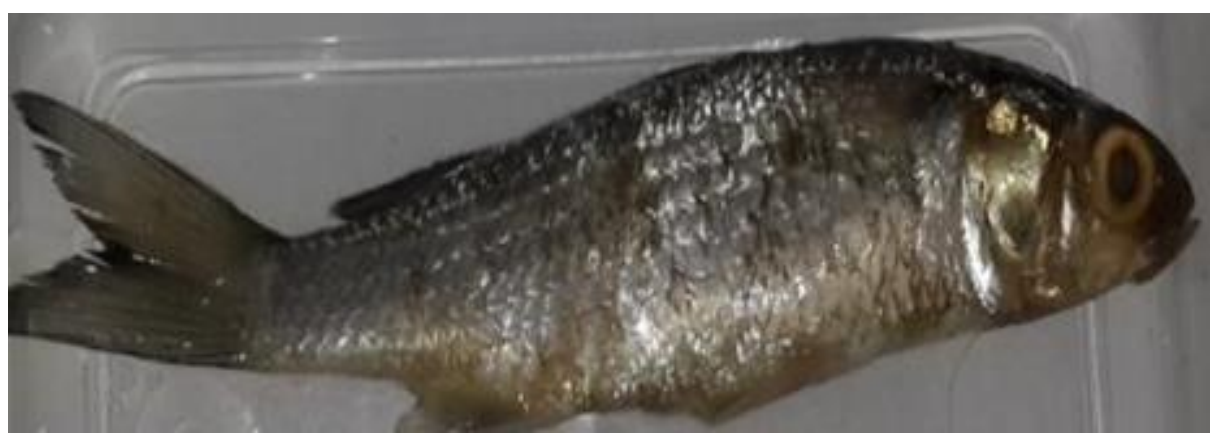

Family: Elopidae

1.1.10. Scientific Name: Elops senegalenesis (Common name: Lady Fish)

Zoogeography: Elops senegalensis is distributed in the eastern Atlantic from Mauritania to Democratic Republic of Congo.

Habitat Preference: Lives in shallow coastal water with sandy muddy substrate, occasionally enters brackish waters and downstream of rivers.

Food and Feeding Habit: Fish, shrimps, carnivorous. 
Reproduction: Oviparous, spawn at sea.

Distinguishing Features and Morphology: Lateral line ornamented with none-ramified small tubes, grey-black, silver glossy sides, fin tinted yellow

Economic Importance: Commercial and game fish.

Conservation Status: Least Concern (LC).

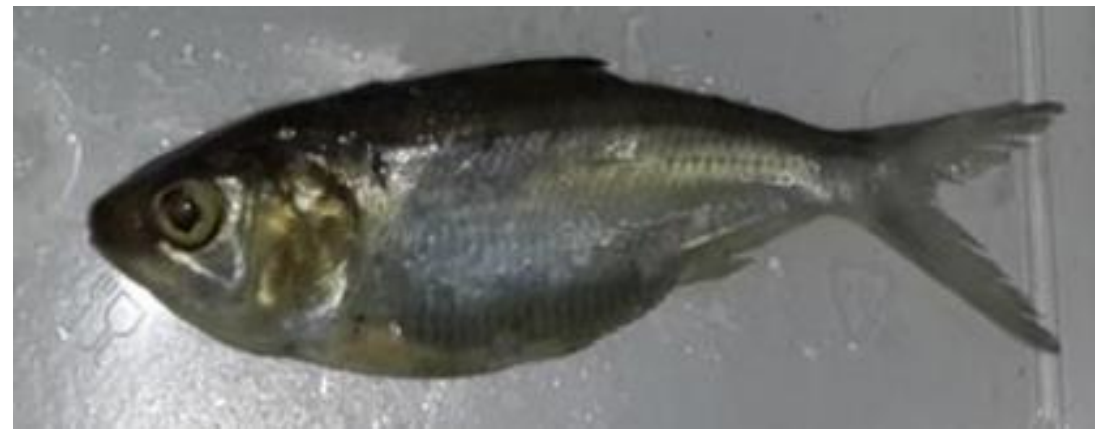

Family: Clupeidae

\subsubsection{Scientific name: Sardinella maderensis (Sardine)}

Zoogeography: They are found in the coastal systems of tropical and subtropical region.

Habitat Preference: They can handle very low salinities when they travel into estuaries and lagoons and spend most of their lives near the surface of water.

Food and Feeding Habit: They feed on phytoplankton and fish larvae.

Reproduction: Spawns only once in a year, during warm weather.

Distinguishing Features and Morphology: It is elongated, while also having a variably protruding belly. These fish have a median number of gill rakers and their upper pectoral fin rays are white on the outer side with a black membrane in between.

Economic Importance: Commercial.

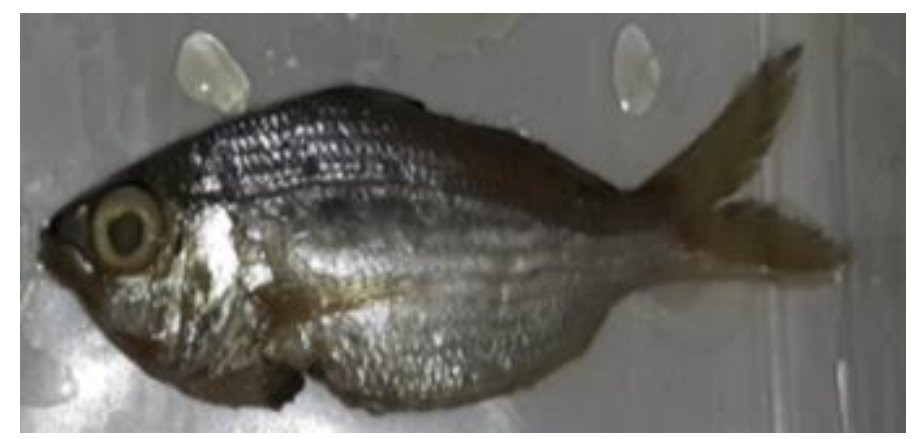

Family: Haemulidae

1.1.12. Scientific name: Brachydeuterus auritus (Bigeye grunt)

Zoogeography: Eastern Atlantic: Morocco to Angola.

Habitat Preference: Inhabits coastal waters. Occur over sandy and muddy bottom between 10 and $100 \mathrm{~m}$ depth but is more common between $30-50 \mathrm{~m}$. 
Food and Feeding Habit: Invertebrates and small fishes. Carnivorous.

Reproduction: Oviparous.

Distinguishing Features and Morphology: Dorsal spines (total):12; dorsal soft rays (total); 11-14, Anal spines: 3, Anal soft rays: 9. Mouth large and oblique, eyes large, silver grey in colour, fins grey.

Economic Importance: Highly commercial.

Conservation Status: Not evaluated

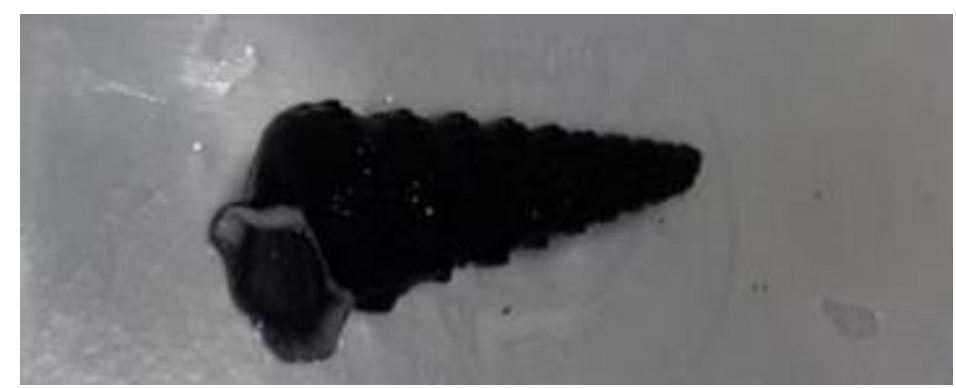

Family: Potamididae

1.1.13. Scientific name: Tympanotonus fuscatus (Periwinkle).

Zoogeography: It is found all along the coast of central Africa. It is also found in the river mouths along the Angolan coast. It is known from Senegal to Cameroon and generally West Africa.

Habitat: This species is found in brackish water. They are bottom dwellers.

Food and Feeding Habit: Omnivorous/ filter feeders, Deposit feeders.

Reproduction: They are hermaphrodites.

Distinguishing Features and Morphology: Characterized by turreted granular and spiny shells with tapering ends.

Economic Importance: It serves as a good source of protein food.

Conservation Status: No specific conservation measures in place for this species. Less concern.

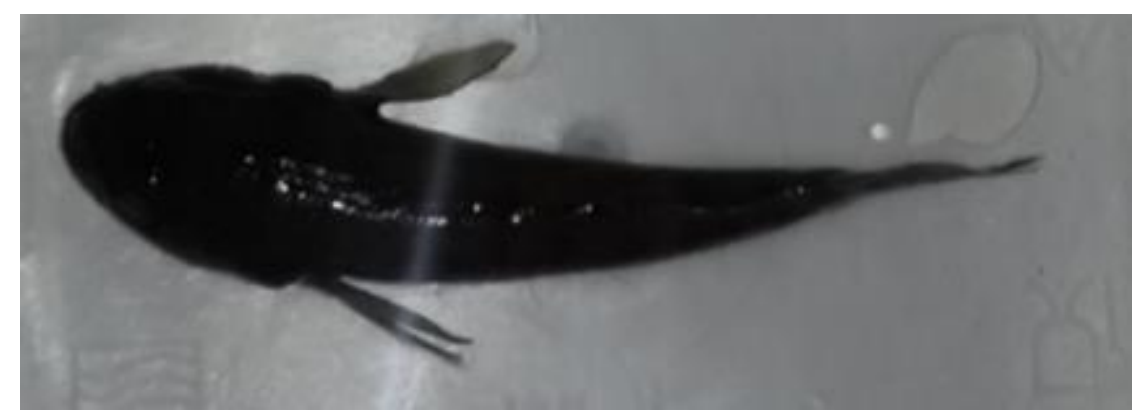

Family: Eleotridae

1.1.14. Scientific name: Eleotris africana (Goby)

Zoogeography: Eastern Atlantic

Habitat Preference: Sandy stony and muddy bottoms of coastal water. 
Food and Feeding Habit: Carnivorous and filter feeders. Filter planktons and arthropods.

Reproduction: Oviparous.

Distinguishing Features and Morphology: Separate pelvic fin, or fused to various extent, mouth never sub-terminal. Dorsal fin 2-8 flexible spines, characterized further by heavy scalation.

Economics Importance: Source of protein food and game fish.

Conservation Status: Red list of threatened species by IUCN.

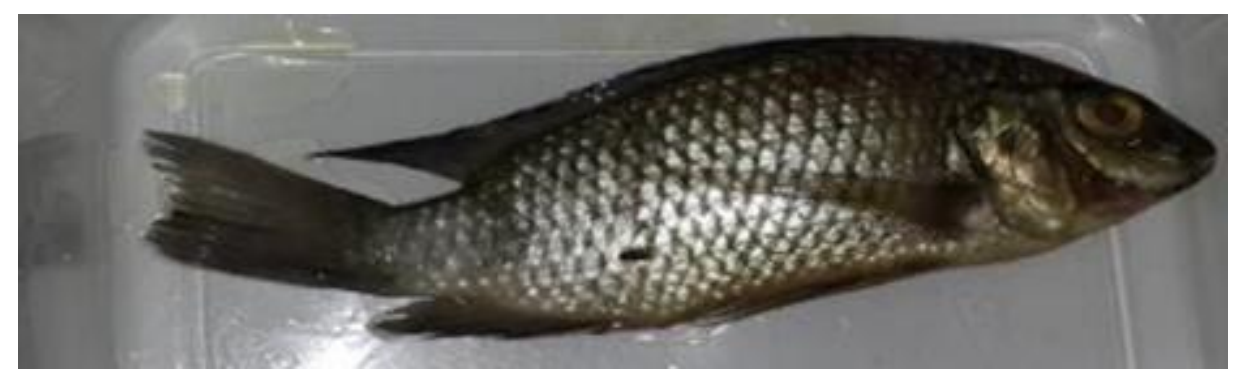

Family: Cichlidae

\subsubsection{Scientific name: Tilapia guineensis (Tilapia)}

Zoogeography: African coastal basins, fresh waters, brackish and marine water from mouth of Senegal River to Mouth of River Angola.

Habitat: There is a benthopelagic species that feeds on shrimps, bivalves, plankton and detritus.

Food and Feeding Habit: Feed on shrimps, bivalves, plankton and detritus (Omnivorous).

Reproduction: They are oviparous. Substrate guarding of eggs as a form of parental care is done by male and female. In Casamance, the reproductive activity appears to be at a maximum in March and April

Distinguishing Features and Morphology: The visual coloration of T. guineensis is shiny, dark greenish yellow and back and flanks becoming lighter in shade near abdomen. The lower lip is white. The tail is bluish-grey. All scales on the flanks have a black spot at the base.

Economic Importance: Commercial fish

Conservation Status: Red list of threatened species by IUCN

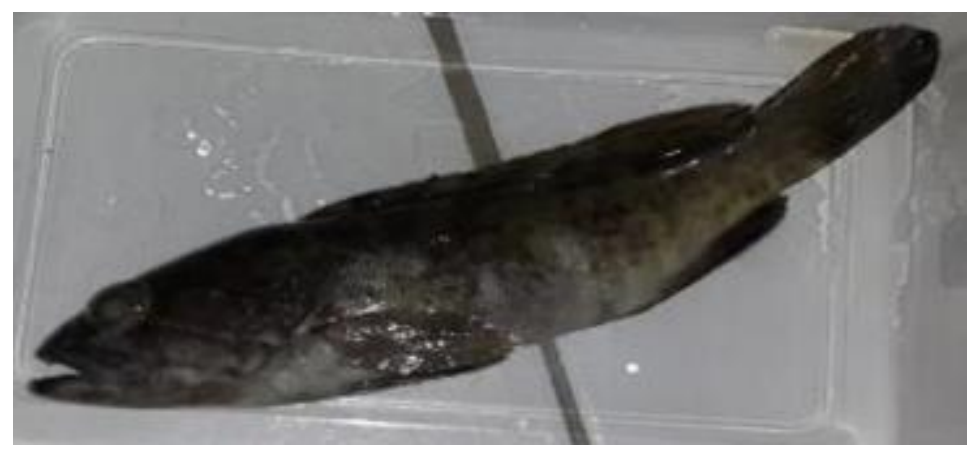

Family name: Epinephelidae 


\subsubsection{Scientific Name: Epinephelus aeneus (White grouper)}

Zoogeography: Subtropical, eastern Atlantic along the west coast of Africa Southern Angola, including southern Mediterranean.

Habitat Preference: Marine, brackish, demersal, oceanodromous, depth range 20-60m.

Food and Feeding Habits: They feed on fishes, crabs and cephalopods.

Reproduction: It is a protogynous hermaphrodite.

Distinguishing Features and Morphology: Depth of body less than head length, inter-orbital area convex, preopercle angular.

Economic Importance: Commercial.

Conservation Status: Red list of threatened species by IUCN

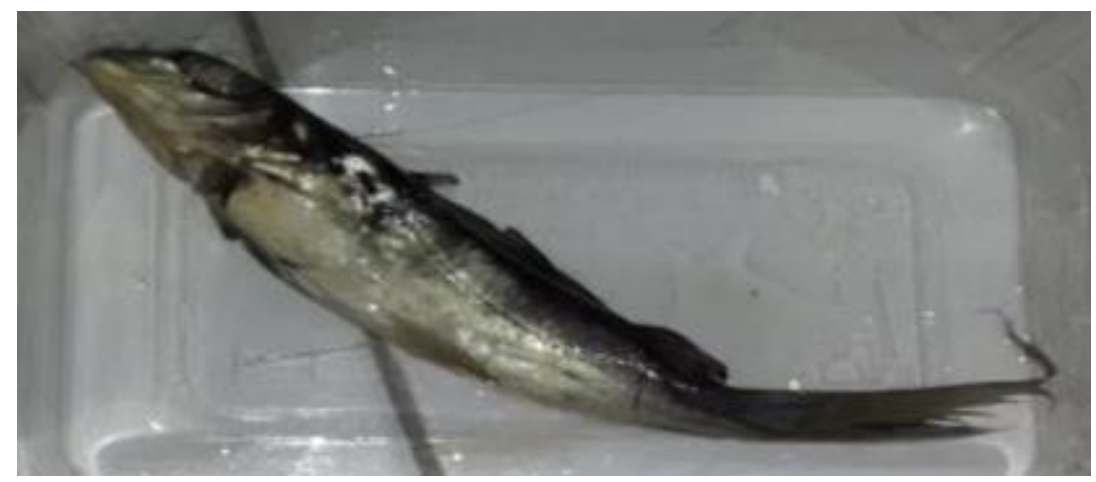

Family: Claroteidae

1.1.17. Scientific Name: Chrysichthys nigrodigitatus (Mud Catfish).

Zoogeography: This species is widely distributed and known from most basins within western Africa. In Southern Africa, it is found in Bengo River systems, and in Cabinda province rivers (Povo Grande).

Habitat Preference: is a dermersal, potamodromous species. It occurs in shallow water of lakes (less than $4 \mathrm{~m}$ ), over mud and fine sand bottom, in rivers and in swamps

Food and Feeding Habit: It is an omnivorous fish that feeds on seeds, insects, bivalves and detritus. Feeding becomes specialized with age on decapods and fish

Reproduction: They are oviparous. They provide parental guard for their young.

Distinguishing Features: Bluish/gray dorsally and ventrally, big-eyes with oval head.

Economic Importance: Commercial fishery, game-fish and aquarium

Conservation Status: Least Concern (LC) 


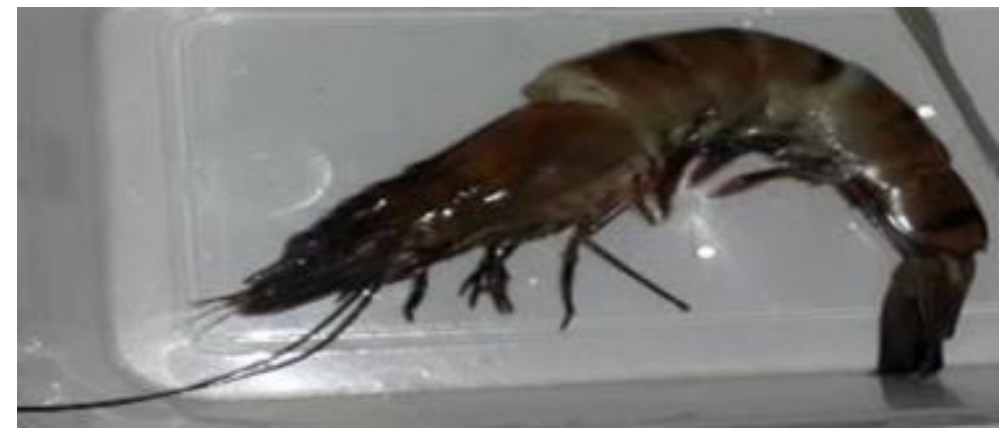

Family: Penaeidae

1.1.18. Scientific Name: Penaeous monodon (Giant Tiger Shrimp).

Zoogeography: Its natural distribution is the Indo-Pacific, ranging from the eastern coast of Africa and the Arabian Peninsula, as far as Southeast Asia, the Sea of Japan, and northern Australia.

Habitat Preference: Penaeus monodon mature and breed only in tropical marine habitats and spend their larval, juvenile, adolescent and sub-adult stages in coastal estuaries, lagoons or mangrove areas. In the wild, they show marked nocturnal activity, burrowing into bottom. Season (July-September).

Food and Feeding Habit: Small crabs, shrimps, bivalves and gastropods. They are carnivorous, detritus filter feeders, omnivorous.

Reproduction: They are oviparous, sperm storing.

Distinguishing Features and Morphology: Females can reach approximately $33 \mathrm{~cm}$ but are typically $25-30 \mathrm{~cm}$ long and weigh 200-320 grams, males are slightly smaller at 20-25 cm long and weighing 100-170 gram.

Economic Importance: For protein food.

Conservation Status: No specific conservation status that is not evaluated.

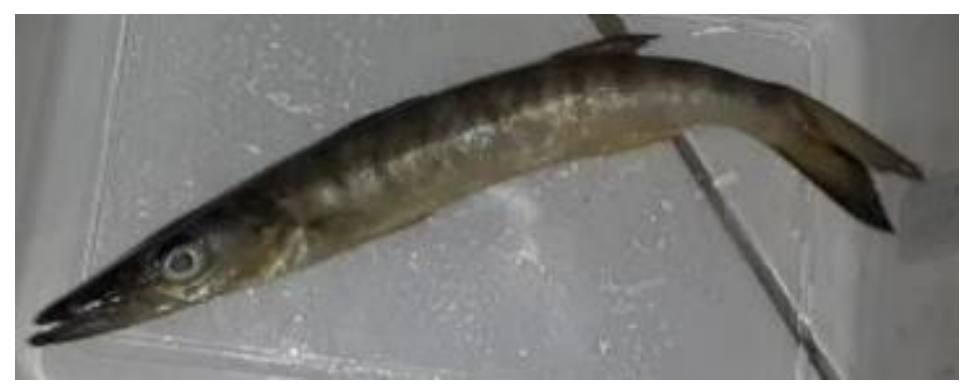

Family: Sphyraenidae

\subsubsection{Scientific Name: Sphyraenidae sphyraenidae (Barracuda)}

Zoogeography: North-Western Atlantic, (USA), Bermuda and throughout the Caribbean Sea to Brazil, found in warm water nearly worldwide.

Habitat Preference: Adult great barracudas live in and around the edges of coral reefs. They tend to avoid brackish water unless they are getting ready to spawn.

Food and Feeding Habits: They eat other fish, they are piscivorous.

Reproduction: They are oviparous. 
Distinguishing Features and Morphology: Barracuda is dark blue, dark green or grayon, its upper body with silvery sides and chalky-white belly. Coloration varies somewhat between species.

Economic Importance: They are popular both as food and game fish.

Conservation Status: Not Evaluated

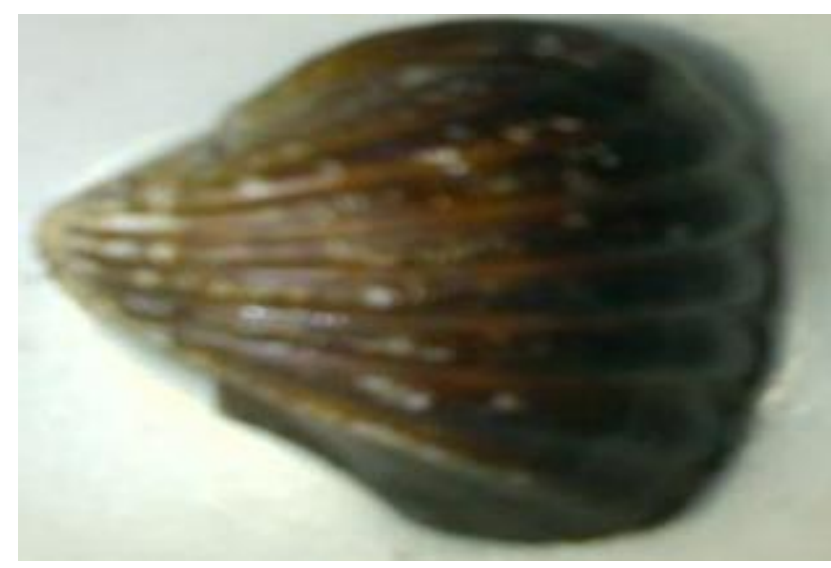

Family: Arcridae

1.1.20. Scientific Name: Anadera senilis (West African Bloody Cockle)

Zoogeography: It is common in many West Africa Estuaries and Lagoons. It is endemic to West Africa and occurs from Rio-de-Ore in the north to Angola.

Habitat: Pre-sediment

Food and Feeding Habit: Detritus Filter feeders.

Reproduction: Ovoviviparous.

Distinguishing Features and Morphology: It has a physical characteristics like laterally compressed bodies enclosed by a shell in two parts called valves hinged on flexible ligament, the hinge is located in the sigittal plane, the shell is bilaterally symmetric, interlocking teeth help the valve interlock, they do not have a brain.

Economic Importance: Food, commercial and decoration.

Conservation Status. Threatened List.

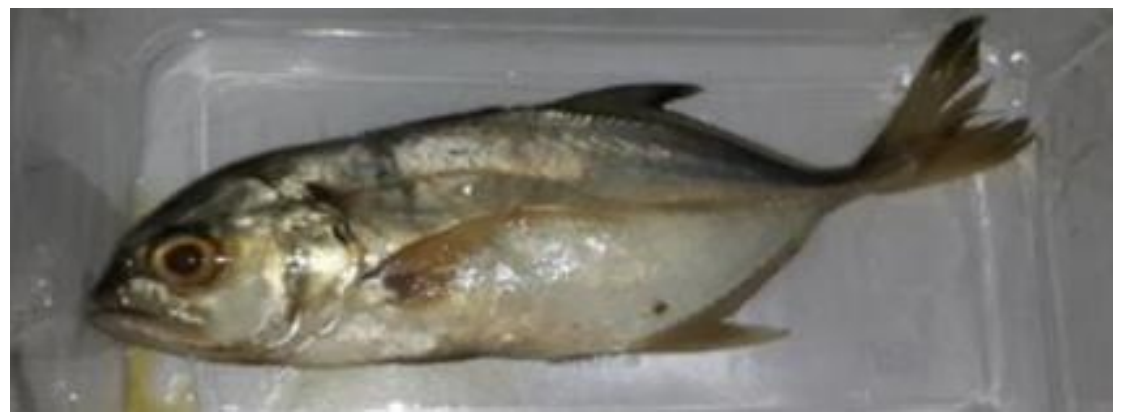

Family: Carangidae 


\subsubsection{Scientific Name: Carax latus (Horse-eye Jacks)}

Zoogeography: The horse-eye jack is commonly found in the subtropical Atlantic Ocean from Bermuda and the northern Gulf of Mexico and south to Rio de Janeiro. In the eastern Atlantic, it is found from St. Paul's Rocks to Ascension Island and, rarely, the in the Gulf of Guinea

Habitat: It is a pelagic fish. It can be found on reefs and offshore oil rigs. The juvenile can be found closer to shore along sandy and muddy bottoms. The species may venture into brackish waters and can live in river mouths, but it is typically found in saltwater up to $140 \mathrm{~m}$ in depth.

Food and Feeding Habit: Horse-eye jacks, Carax latus, feed on small fishes, shrimps and other invertebrates, that is they are carnivorous in nature.

Reproduction: Reproduces via dioecism (sexes are separate), fertilization is external with an unknown spawning frequency in June, July, and August.

Distinguishing Features and Morphology: Horse-eye jacks are similar in body shape to other jacks in the family Carangidae, but their head is not as blunt. Their fins are blackish as opposed to the yellow tinge of crevalle jacks. As their name indicates, their eyes are very large. These fish have 8-9 dorsal spines, 20-22 dorsal soft rays, 2-3 anal spines and 16-17 anal soft rays. They have no spots on their pectoral fins. They may have a small spot on their gill covers. Their scutes (bony plates) tend to be dusky or blackish; their caudal (tail) fin is yellow. Their young have broad blackish bars on their bodies.

Economics Importance: Game fish, aquarium fish and minor commercial fish.

Conservation Status: Not evaluated (Least concern)

\subsection{Some Freshwater Fish Species of the Niger Delta Region.}

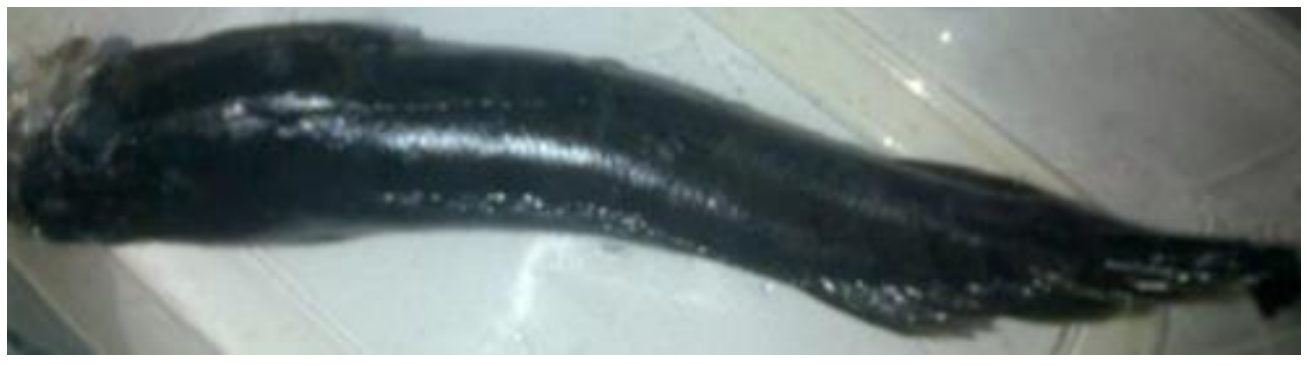

Family: Channidae.

\subsubsection{Scientific name: Channa obscura (Snakehead)}

Zoogeography: White Nile, specifically the Jebel and Ghazal, systems of Sudan and Gambela region of Ethiopia; Lake Chad basin, Zaire, Senegal. Widely distributed in Ghana and Nigeria.

Habitat Preference: Marginal vegetation and floodplain habitat in the Sudan. Streams, rivers, lakes, lagoons and marches in flowing water. Widely distributed in marshy habitats and also found in bank vegetation of river channels.

Reproduction: Cave-spawners/egg-scatterers, Oviparous.

Food and Feeding Habit: Other fishes, copepods and insect larvae. Juveniles feed on prawn, copepods and aquatic insect larvae, Carnivorous.

Distinguishing Features and Morphology: Patches of scales present in the gular region. No canine teeth. Transverse scales 19-24. The fish is depressed anteriorly, relatively long and covered with large scales. Lower jaw is slightly longer then upper jaw, have dark blotches.

Economic Importance: Food, aquarium species and also for culture.

Conservation Status: Least Concern (LC). 


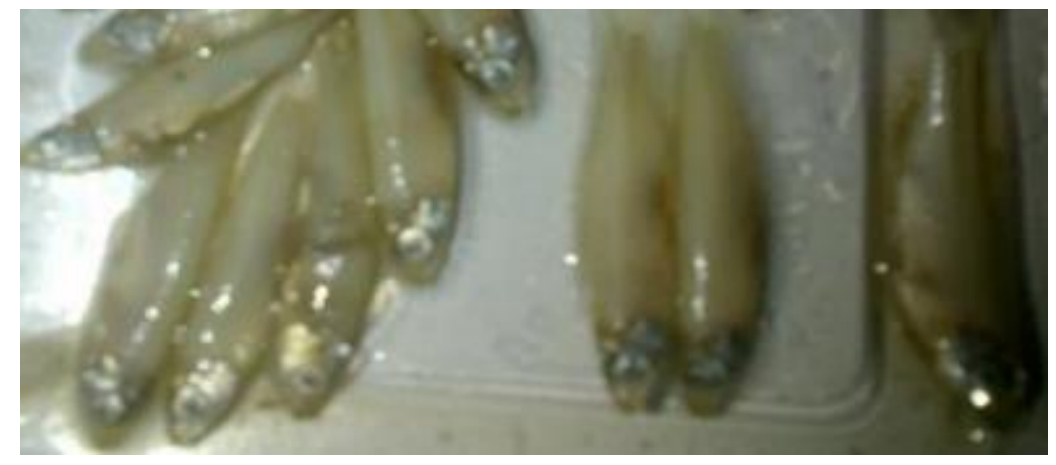

Family: Clupidae

\subsubsection{Scientific name: Alosa aestivalis (Blueback Herring)}

Zoogeography: East coast of North America from cape Breton, St Johns River in Florida. Atlantic coast of Cape Breton, Nova Scutes, Florida.

Distinguishing Features and Morphology: Silvery in colour, have a series of scutes (modified, spiny and keeled scales) along their bellies, deep bluish-green backs. Block to dusky in colour of its peritoneam (the living of the abdominal cavity

Habitat Preference: Anadromous, living in marine systems and spawning in deep swift freshwater, rivers with hard substrates. It migrates to spawning ground in the spring.

Food and Feeding Habit: Planktivores, small fishes, shrimps, carnivorous.

Economic Importance: Fishing industry, human consumption.

Conservation Status: Least Concern.

Reproduction: Oviparous

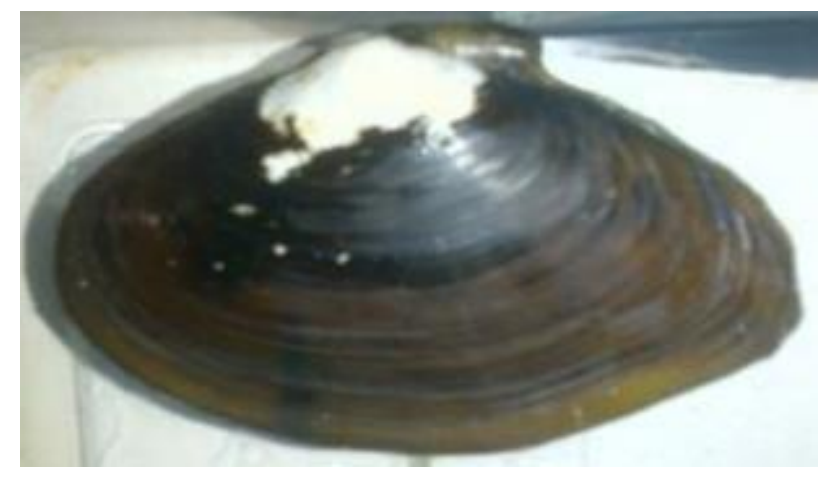

Family: Corbiculidae

\subsubsection{Scientific Name: Corbicula fluminea (Asian Clam)}

Zoogeography: Asian origin, Southwest Asia is known as prosperity clam, North America, Europe.

Food and Feeding Habit: Feed primarily on phytoplankton (algae) which they filter from the sandy or muddy bottom of streams, lakes or canals.

Distinguishing Features and Morphology: The outside of the shell is normally yellow-green with concentric rings. The colour can flake, leaving white spots. The shells are lightly purple on the inside.

Habitat Preference: Found in lake and streams of all sizes with silt, mud, sand and gravel substrate. They can tolerate salinities of up to 13ppt for short period. It is found in moving water because it requires high level of dissolved oxygen. 
Economic Importance: Power plants. It has caused millions of dollars' worth of damage to intake pipes used in power and water industry in US. Bait for fish, as source of food.

Conservation Status: Threatened.

Reproduction: Self-fertilization. Hermaphrodite, Sperm is released into the water caught by another clam, and brooded in the gill.

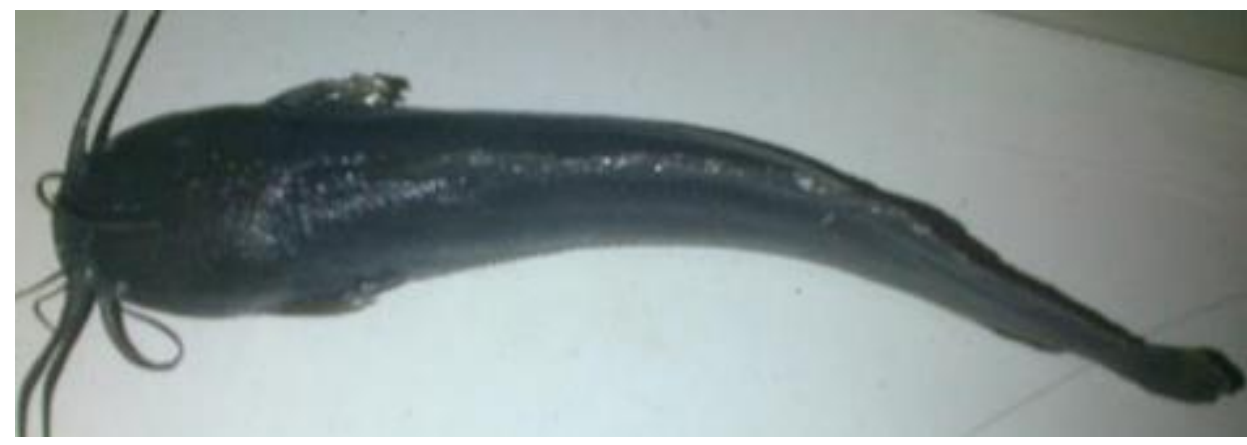

Family: Clariidae

\subsubsection{Scientific Name: Clarias lazera (African Catfish)}

Distinguishing Features and Morphology: Body elongate, head large, depressed and bony with small eyes narrow and angular occipital process, gill opening wide. Long dorsal and anal fin without dorsal fin spine and adipose fin. Caudal fin rounded. Colour varies from sandy-yellow through gray to olive with dark-greenish-brown markings, belly white.

Habitat Preference: Found in lakes, rivers, swamps and floodplain, many of which are subject to seasonal drying. Fresh water, bottom feeder occasionally feed at surface.

Zoogeography: Native to Africa, Niger and Nile river extending to Southern Africa, Israel, Syria, Europe, Asia.

Food and Feeding Habit: Insect (adults and larvae) worm, gastropods, crustaceans, small fish, aquatic plants and debris, birds, small mammals. They are Omnivorous.

Conservation Status: Abundant.

Reproduction: They are oviparous.

Economic Importance: For food, also used to control the population of Tilapia when culture together.

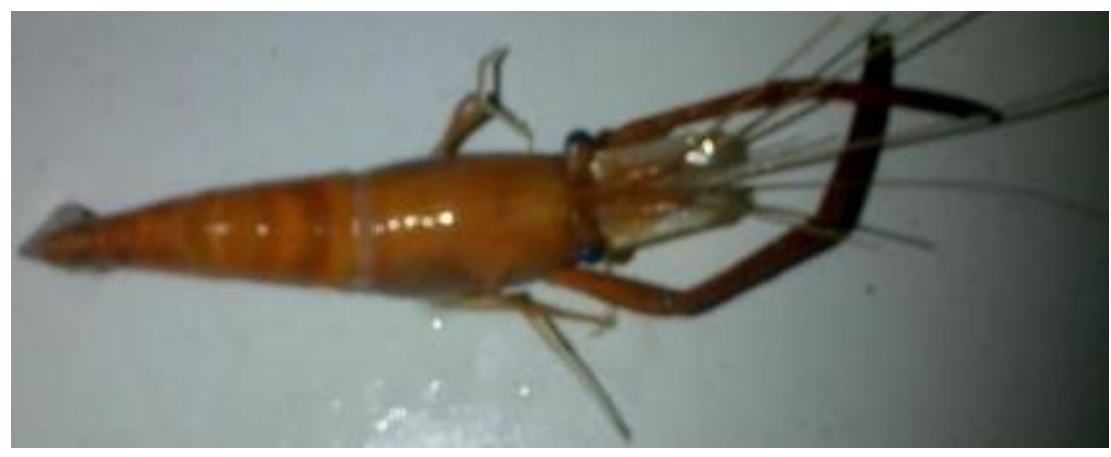

Family: Palaemonidae

\subsubsection{Scientific Name: Macrobrachium roseabergii (Giant River Prawn)}

Distinguishing Features and Morphology: Males can reach a total length of over $320 \mathrm{~mm}$; females $250 \mathrm{~mm}$. Body usually greenish to brownish grey. Sometimes more bluish, darker in larger specimens. Antennae often blue; chelipeds 
blue or orange. 14 somites within cephalothorax covered by large dorsal shield (carapace); carapace smooth and hard, rostrum long.

Zoogeography: Indo-pacific region, Australia, Southeast Asia.

Habitat Preference: Larval stage depends on brackish water from Juvenile fresh water.

Food and Feeding Habit: Pieces of worms, snails, clams, fish, piece of rice, wheat, beans, nuts, aquatic-plant and some fruits. They are omnivorous.

Reproduction: They are oviparous

Conservation Status: Least Concern.

Economic Importance: Food source.

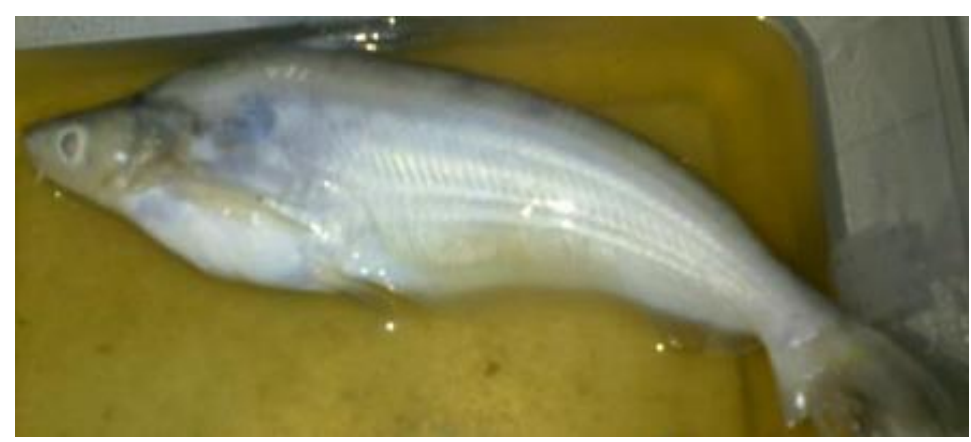

Family: Schilbeidae.

1.2.6. Scientific Name: Schilbe uranoscopus (Butter catfish).

Zoogeography: This species is known from the length of the Nile to Kenya, and Nigeria, Niger, Chad and Cameroon.

Habitat Preference: Freshwater, demersal, potamodromous species. It is found in lake, delta and riverine habitats.

Reproduction: Oviparous, eggs are unguarded.

Conservation Status: Least Concern.

Distinguishing Features and Morphology: Barbels short, 13-16 gill rakers on the lower part of the branchial arch. Head long with large eyes, anal fin rays 59-73, body generally silver-grey.

Food and Feeding Habit: Zooplankton, invertebrates, they are omnivorous filter feeders.

Economic Importance: It is a good source of food.

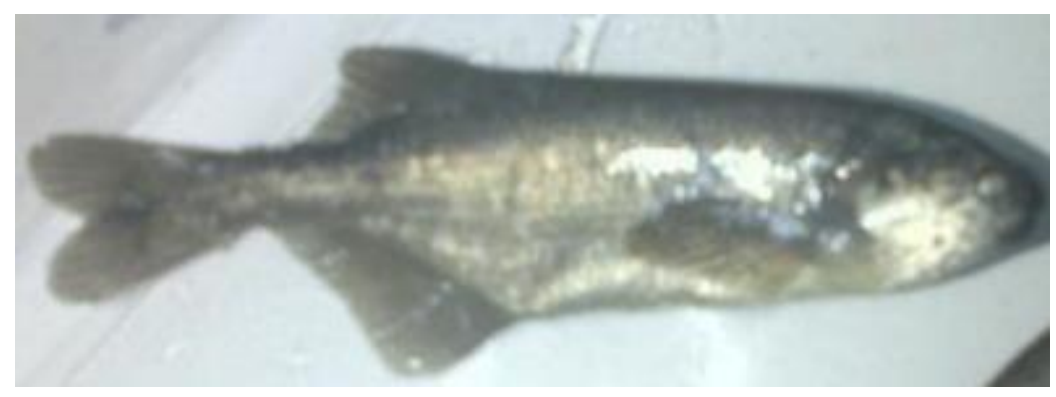

Family: Mormyridae 


\subsubsection{Scientific Name: Marcusenius ihuysi}

Distinguishing Features and Morphology: Dorsal fin rays 17-23, Anal fin rays 23-25, lateral lines, and scales 48-53, caudal peduncle rounded.

Zoogeography: They are tropical fish.

Habitat Preference: It inhabits streams, swamps, rivers and lakes. It is bottom dweller and feeder. They are usually found in groups.

Food and Feeding Habit: Algae, insect larvae, detritus, omnivorous feeders.

\section{Conservation Status: Common}

Economic Importance: Food source, good for aquarium, used for animal feeds and as bait for catching bigger fishes.

Reproduction: They are oviparous.

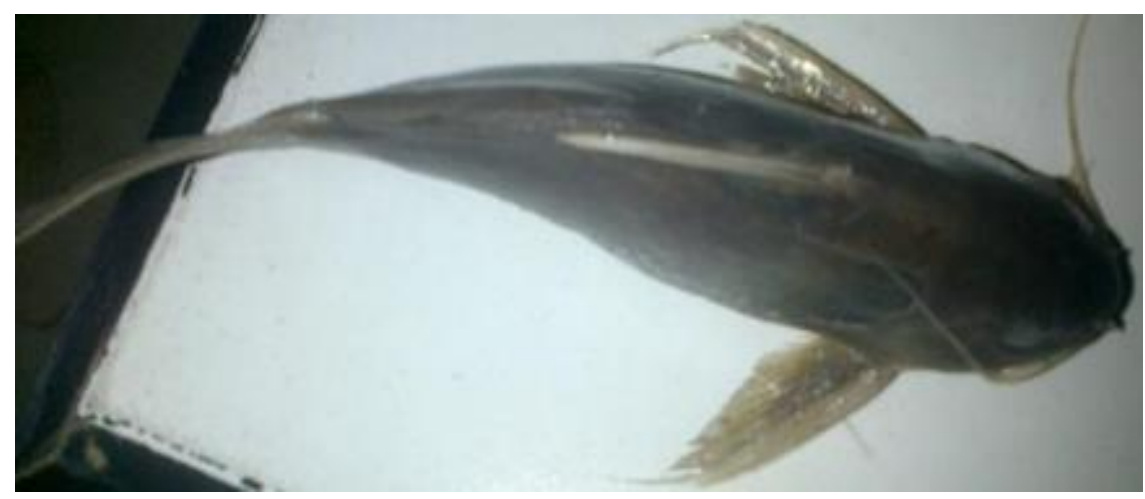

Family: Mochokidae

\subsubsection{Scientific Name: Synodontis membranaceus (Moustache Catfish)}

Distinguishing Features and Morphology: They can be recognized by the unusually wide membranes on its barbells that give the appearance of a moustache. These fish are patterned with a few large spots on their body that fade quickly with growth. There is a comb of very small spines near the point of the operculum, but they do not protrude through the skin.

Zoogeography: Africa: Chad, Niger (including the Benin),Senegal, Gambia, and Volta basins, also the Nile in the northern Africa

Habitat Preference: Freshwater; Benthopelagic, occurs in deep waters close to the shore.

Food and Feeding Habit: Feed on, plankton surface insects, chironomid larvae, benthic crustaceans, and mollusks. They are Omnivorous.

\section{Reproduction: Oviparous}

Economic Importance: Is a component of local commercial fisheries.

Conservation Status: Least Concern. 


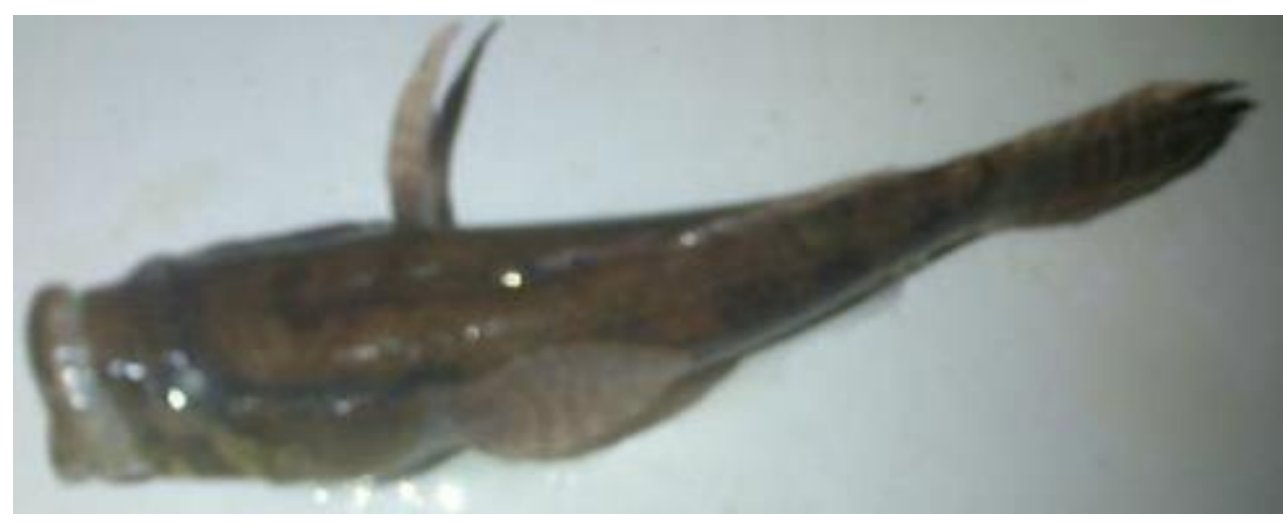

Family: Eleotridae

1.2.9. Scientific Name: Bostrychus africanus (Sleeper or sleeping gobies).

Distinguishing Features and Morphology: Body feebly compressed head little longer than its breath Snout broad and rounded. Jaw equal in front. Pectoral fin longer than pelvic fin, lateral line scales 90-95, brown dorsally and whitish ventrally. Fins purple. The lower borders of outer border of ventral fins white.

Zoogeography: This species is a tropical fish. It has been reported from Senegal to Angola

Habitats: It is a brackish water fish that ascends into freshwaters. It inhabits littoral waters. It is demersal and amphidromous.

Food and Feeding Habit: Its food items include small crabs, insects and plankton. It is omnivorous feeder.

Reproduction: They are oviparous.

Conservation Status: Least Concern.

Economic Importance: Human food, it is used as baits by fishermen.

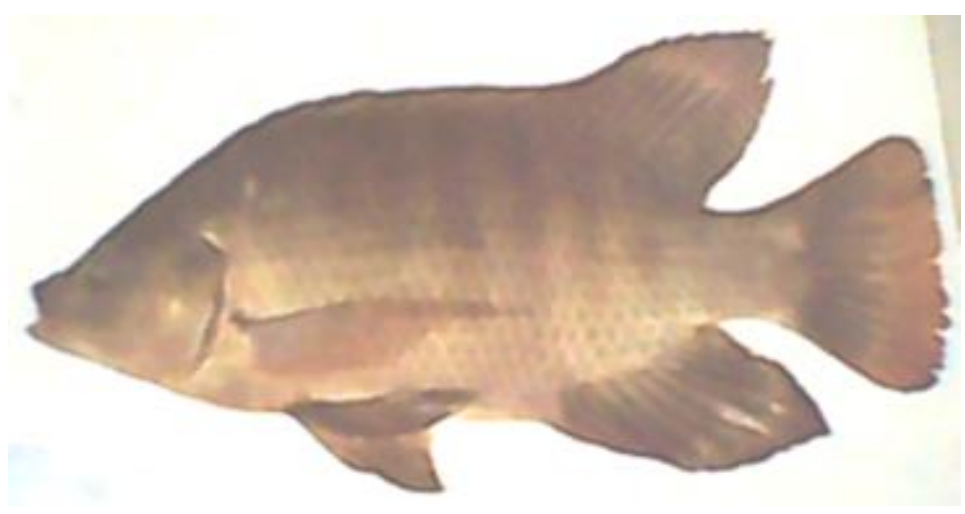

Family: Cichlidae

1.2.10. Scientific Name: Oreochromis niloticus. (Nile Tilapia)

Distinguishing Features and Morphology: The Nile tilapia has distinctive, regular, vertical stripes extending as far down the body as the bottom edge of the caudal fin, with variable coloration. Adults reach up to $60 \mathrm{~cm}(24 \mathrm{in})$ in length and up to $4.3 \mathrm{~kg}(9.5 \mathrm{lb})$

\section{Zoogeography:}

Habitat Preference: The Nile tilapia thrives on the warmer temperatures commonly found in shallow waters compared to the colder environment of the deep lake 
Reproduction: The Nile tilapia reproduces through mass spawning of a brood within a nest made by the male. They are oviparous.

Food and Feeding Habits: Omnivore, feeding on plankton as well as on higher plants.

Economic Importance: Good source of protein.

Conservation Status: Least Concern.

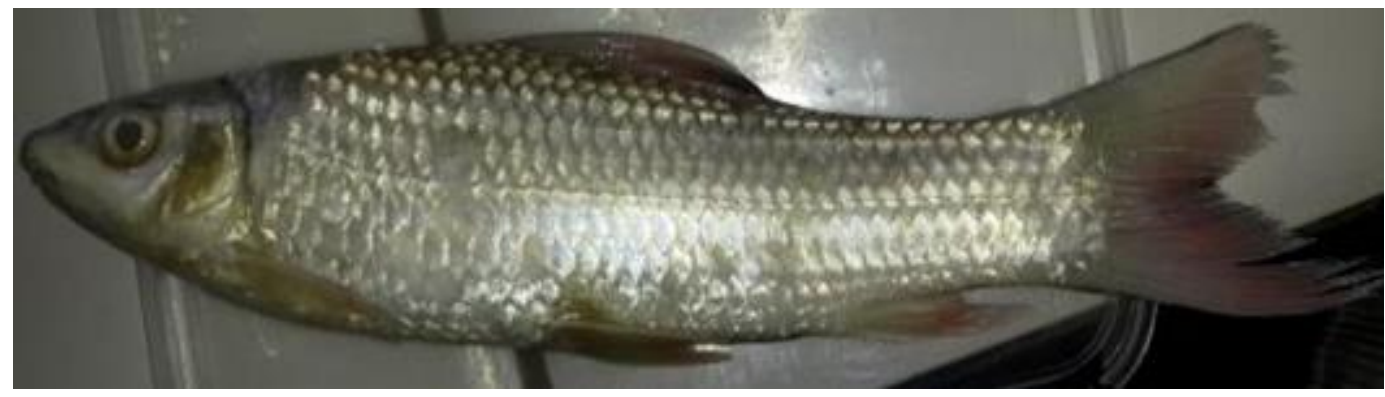

Family: Alestidae

1.2.11. Scientific Name: Brycinus nurse (Old name Alestes nurse) (Feather fin Fish).

Distinguishing Features and Morphology: Anal spines: 0; Anal soft rays: 13 - 18. Diagnosis: fronto-parietal fontanel absent in adults, sometimes pore-like in juveniles, disappearing with growth; dorsal fin origin at about same level as pelvic fin insertion; sexual dimorphism affecting anal fin shape; 24-34 lateral line scales; 5.5 scales between lateral line and dorsal fin; 10-15 anal fin branched rays; 14-20 gill rakers on lower limb of first gill arch; 8 teeth in outer premaxillary row. Snout short, more than 3x head length; head length/snout length 3.6-4.3; 10-11.5 pre-dorsal scales; flanks without lateral band; adults medium-sized

Zoogeography: Africa: widely distributed in West Africa. In Lower Guinea present in Cross and Mémé rivers.

Habitant Preference: Freshwater; pelagic; pH range: 6.0 - 7.8; dH range: 1 - 30; potamodromous

Reproduction: They are oviparous.

Food and Feeding Habits: Feeds on zooplankton, Caridina, insects, snails and vegetation, they are omnivore

Economic Importance: Fisheries: minor commercial; aquarium: commercial.

Conservation Status: Not evaluated

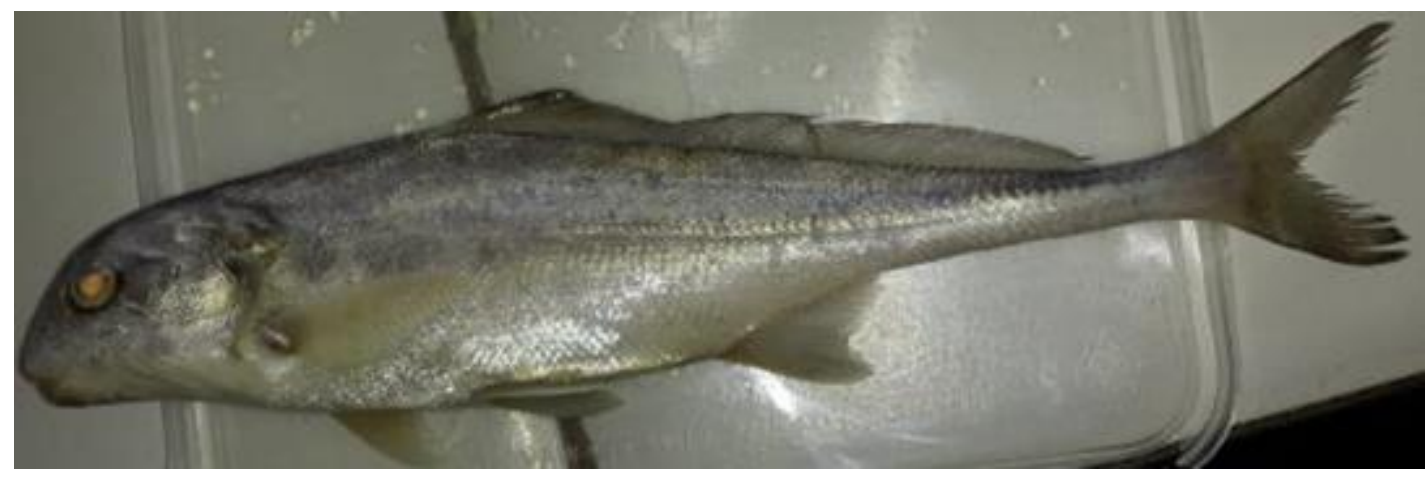

Family: Mormyridae.

1.2.12. Scientific Name; Mormyrus macrophthalmus

Zoogeography: Africa: Niger and Volta basins. Also known from the Bénoué basin in Cameroon 
Habitat Preference: Freshwater; demersal; potamodromous. Tropical

Distinguishing Features and Morphology: Dorsal spines (total): 0; Dorsal soft rays (total): 59-68; Anal soft rays: 18 22. very short snout, massive and rounded; mouth opens before eyes; anal fin base 3.8-4.9x of dorsal fin base; $12-16$ scales on caudal peduncle; caudal peduncle height 2.5-3.0x body length; SL 3.4-5.0x body weight.

Reproduction: Oviparous.

Food and Feeding Habits: Feeds on benthos, zooplankton, algae, diatoms, and detritus. They are omnivorous.

Economic Importance: Commercial, game fish, also used as aquarium fish.

Conservation Status: Not evaluated, that is Least Concern.

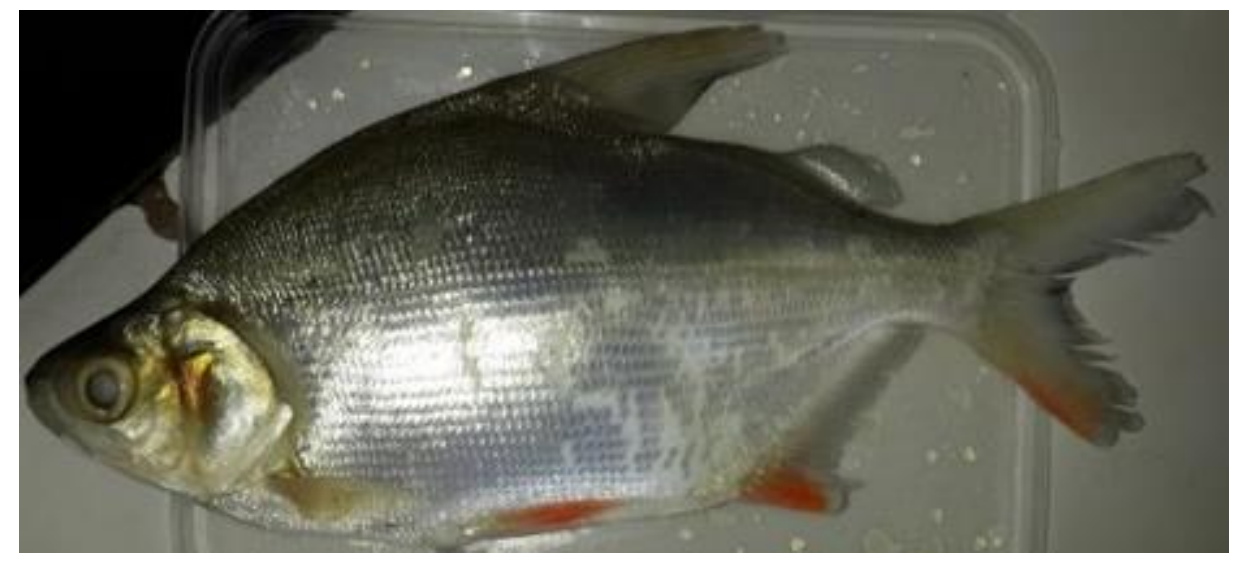

Family: Citharinidae

\subsubsection{Scientific Name: Citharinus citherus (Moon Fish)}

Zoogeography: Africa: Gambia, Senegal, Niger, Volta, Ouémé and Chad basins

Habitat Preference: Freshwater; demersal; anadromous

Distinguishing Features and Morphology: Dorsal soft rays (total): 17-21; Anal soft rays: 26 - 31 . Diagnosis: body depth 1.8-2.7x and head length 3.0-4.1x SL; caudal peduncle 0.7-1.4x long than deep; short snout, slightly prominent; snout 0.7-1.6x eye diameter; eye diameter 3.7-6.1x head length; adipose-fin base shorter than distance separating it from rayed dorsal fin (ratio adipose base/distance to rayed dorsal is $0.5-0.8$ ); pectoral fins $0.5-1.1 x$ head length; cycloid scales; scale formula 22.5-25.5/77-92/22.5-25.5; 77-92 scales in longitudinal line; 17.5-20.5 scales between lateral line and pelvic fin; 17-21 dorsal fin branched rays; 26-30 anal fin branched rays.

Reproduction: Oviparous.

Food and Feeding Habit: Detritus, Omnivorous.

Economic Importance: Commercial fish and aquarium.

Conservation Status: Not evaluated. 


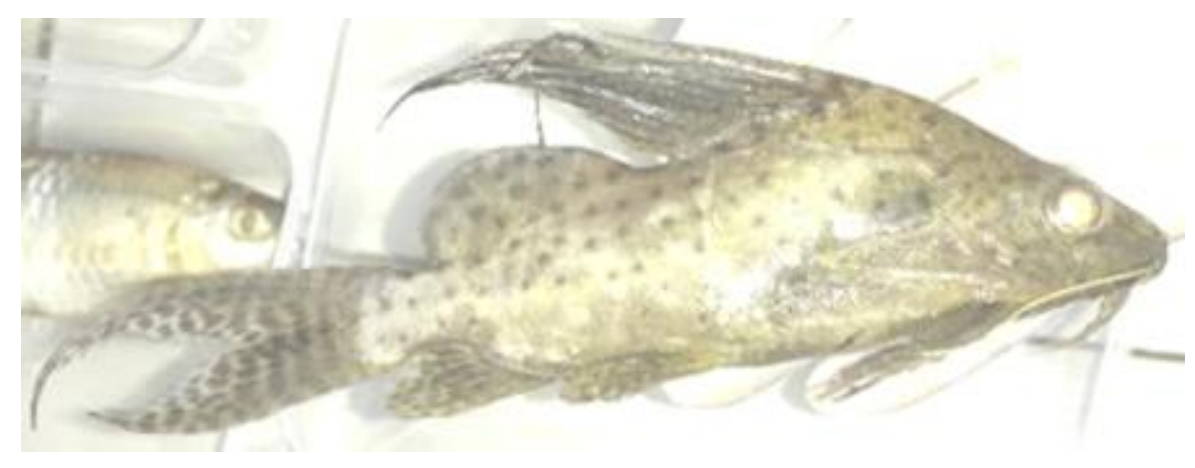

Family: Mochokidae

1.2.14. Scientific Name: Synodontis eupterus (Feather fin Squeaker)

Zoogeography: African Waters, Nile, Upper Nile, White Nile.

Habitat Preference: Live near muddy or rocky bottoms of rivers.

Distinguishing Features and Morphology: Has very long soft rays in its dorsal fin, giving it a sail-like appearance. The body is olive dotted all over with small black spots except the belly which is white.

Reproduction: Oviparous.

Food and Feeding Habit: They are omnivorous

Economic Importance: Aquarium and commercial fish.

Conservation Status: Not evaluated.

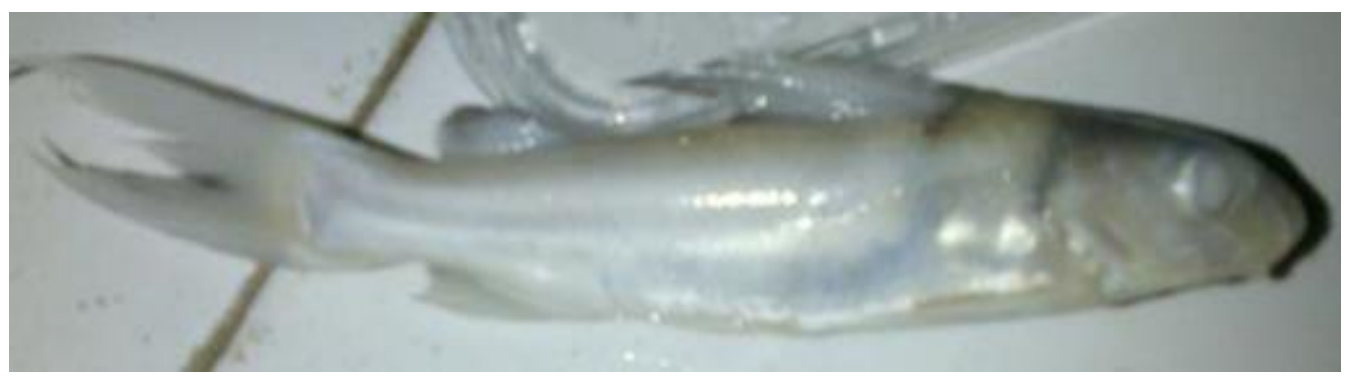

Family: Claroteidae.

\subsubsection{Scientific Name: Chrysicthys nigrodigitatus (Fresh-Water)}

Zoogeography: Africa: Senegal to Cabinda, Angola, reported from Mauritania. Also present in the lower Congo River.

Habitat Preference: Chrysichthys nigrodigitatus is a demersal, potamodromous species. It occurs in shallow waters of lakes (less than $4 \mathrm{~m}$ ), over mud and fine sand bottom, in rivers and in swamps

Distinguishing Features and Morphology: bluish/gray dorsally and ventrally, big-eyes with oval head

Food and Feeding Habit: Omnivorous, feed on seeds, insects, bivalves and detritus. Feeding becomes specialized with age and size, larger fish may feed on decapods and fish

Conservation Status: Not evaluated.

Reproduction: Oviparous.

Economic Importance: commercial fisheries. 


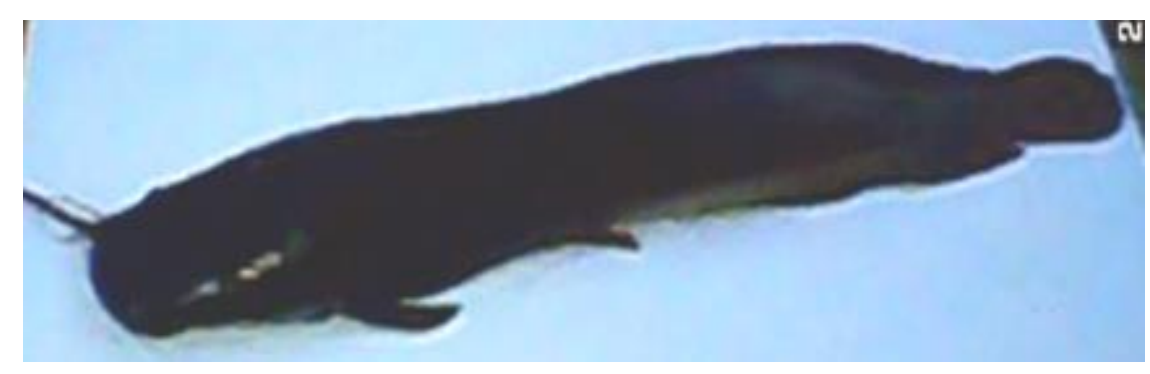

Family: Clariidae

1.2.16. Scientific Name: Clarias gariepinus (African Catfish)

Zoogeography: Found throughout Africa and Middle-East; can crawl on dry ground to escape drying pools.

Habitat Preference: Freshwater lakes, rivers and swamps

Distinguishing Features and Morphology: They are recognized by their long-based dorsal and anal fins, which give them an eel-like appearance. These fishes have slender bodies, a flat bony head, and a broad, terminal mouth with four pairs of barbels. They also have large accessory gill arches.

Reproduction: They are oviparous.

Food and Feeding Habits: Feeds on living and dead animal matters. Carnivorous

Economic Importance: Commercial important fish consumed by human, can also be used in the production of fish feed.

Conservation Status: Least Concern.

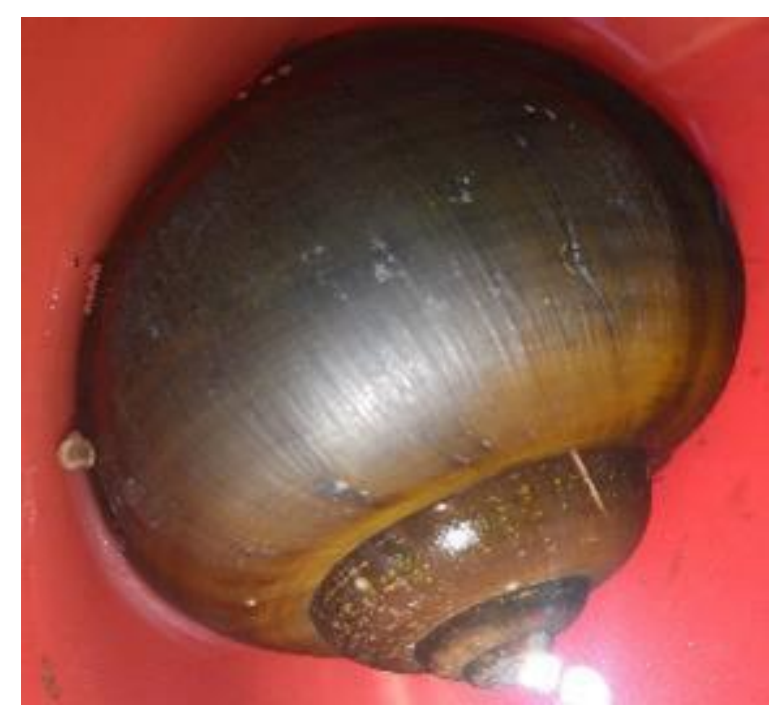

Family: Ampullariidae

1.2.17. Scientific Name: Pila ovate (Water Snail)

Zoogeography: Found in Africa, Madagascar, South Asia and Indo-Pacific Island.

Habitat Preference: Fresh water

Distinguishing Features and Morphology: Has a relatively high spine (about half the overture height) and a round shell opening (overture). The umbilicus is small, but deep and the lip is somewhat thickened. The colour varies from light brown to reddish olive with faint, non-continuous spiral bands. 
Food and Feeding Habit: Various water plants, Herbivorous

Reproduction: Hermaphrodite

Economic Importance: Good for food and the shell is used in artistry and also grinded for fish meal.

Conservation Status: Least Concern.

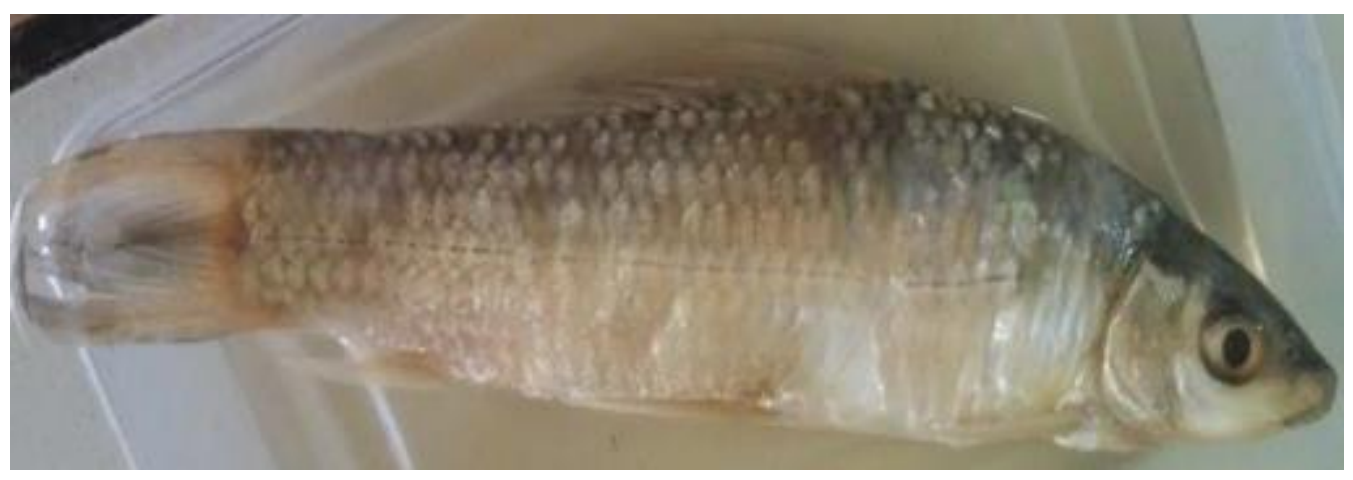

Family: Cyprinidae

\subsubsection{Scientific Name: Labeo coubie}

Zoogeography: It is known from Senegal to Ethiopia, with populations present in the Nile, it is native to Africa.

Habitat Preference: Fresh water; benthopelagic, potamodromous

Distinguishing Features and Morphology: 4 dorsal spines, 11-15 dorsal soft rays, 3 anal spines, 5-8 anal soft rays, 3133 vertebrae, body dark and full, rostral lobe is poorly developed, inner surface of lips with transverse fold, presence of caudal peduncle, gill rakers, 4.5 scales between lateral line and pelvic base. 12-14 dorsal fin branched rays.

Food and Feeding Habit: Bottom feeder, on mud, diatoms and debris; Detritivore

Reproduction: Oviparous

Economic Importance: Good for food, important for commercial fisheries, also used in aquarium.

Conservation Status: Least Concern.

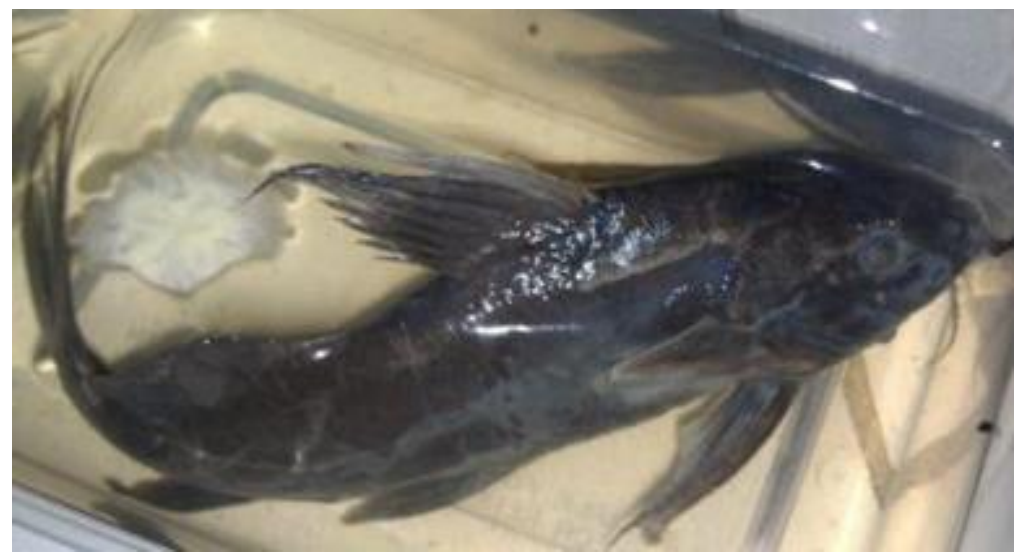

Family: Mochokidae

1.2.18. Scientific Name: Synodontis budgetti

Zoogeography: Native to Benin, Cameroon, Guinea, Mali, Niger and Nigeria. 
Habitat Preference: Fresh water; benthopalegic

Distinguishing Features and Morphology: Has a hardened head cap that has attached process (humeral process) which is situated behind the gill opening and pointed towards the posterior. The dorsal fin and pectoral fins have a hardened first ray which is serrated. Caudal fin is always forked. There is one pair of maxillary burbles, sometimes having membranes and occasionally branched. The two pairs of mandibular barbells are often branched and can have nodes attached. The cone-shaped teeth in the upper jaw are short, s-shaped and moveable in the jaw.

Food and Feeding Habit: Insects, crustaceans, mollusks, annelids, seeds and algae; Omnivore

\section{Reproduction: Oviparous}

Economic Importance: Commercial fisheries

Conservation Status: Least Concern.

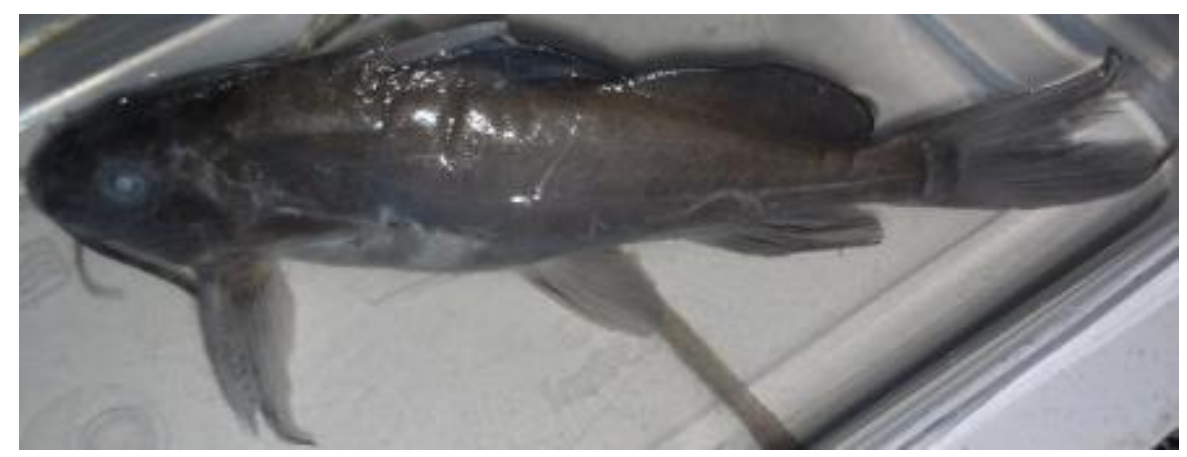

Family: Bagridae

1.2.19. Scienific Name: Bagrus bayad

Zoogeography: Found in Africa; Nile River, Lake Chad, Niger and Senegal, Lake Mobutu and Turkana.

Habitat Preference: Fresh water; lakes, swamps and rivers

Distinguishing Features and Morphology: Dorsal spine is present, 8-12 dorsal soft rays, 13-15 anal soft rays, 48-53 vertebrae, body is more or less elongated, and head is much depressed, smooth above. Supra-lateral eyes with a free orbital margin. Posterior and anterior nostrils are remote from each other, the posterior being provided with a barbell. Dorsal fin with smooth spine, lobes of caudal fin often with short filaments. Pelvic fin inserted under 5 th or 6 th branched ray of dorsal fin. Lateral line consist of a straight line of tubular elevations, from scapular to the mid of the caudal fin.

Food and Feeding Habit: Feed on insects, crustaceans, mollusks, vegetable matter, preys on small fish; Predatory Omnivore (Piscivorous)

Reproduction: Oviparous

Economic Importance: Important food fish.

Conservation Status: Not evaluated. 


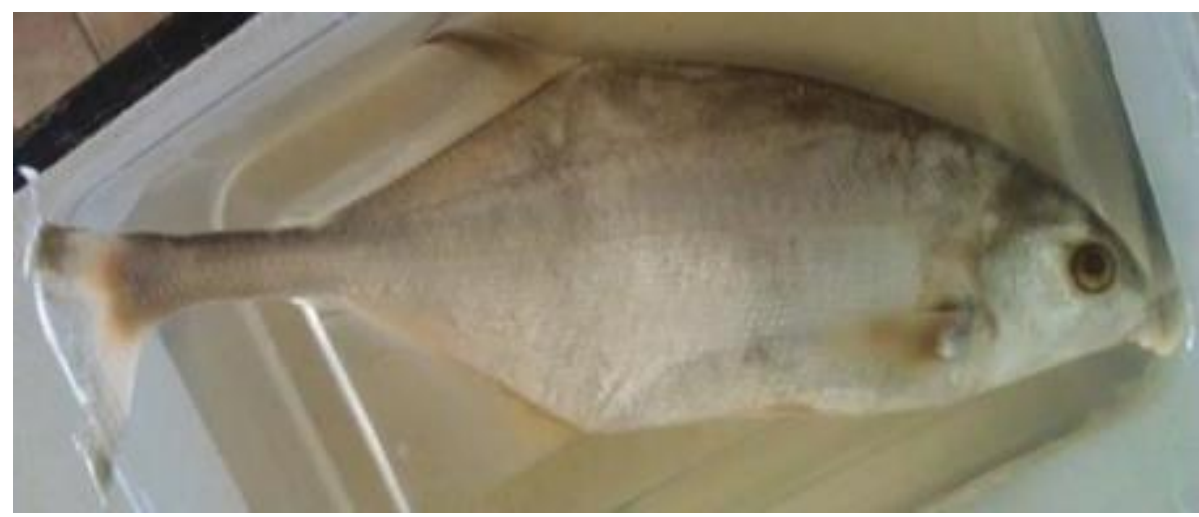

Family: Mormyridae

\subsubsection{Scientific Name: Marcusenius abadii}

Zoogeography: Found in West Africa.

Distinguishing Features and Morphology: Has dorsal fin originating in advance of the anal fin and the body deepest at the origin of the dorsal fin. The chin is slightly elongated with globular appendage. The colour is uniformly light brown, slightly darker on the back. The anterior rays on the dorsal and anal fins sometimes have trances and darker bars.

Habitat Preference: Fresh water; demersal.

Food and Feeding Habit: Feed on insects, mollusks and crustaceans; Carnivore

Reproduction: Oviparous

Economic Importance: Important for food and commercial fisheries.

Conservation Status: Least Concern.

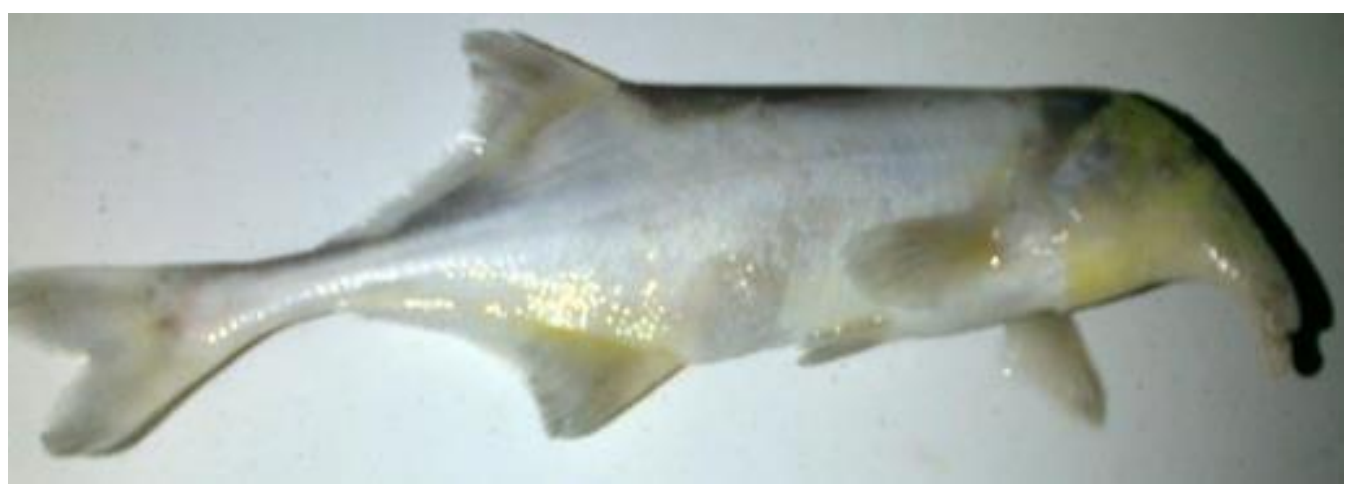

Family: Mormyridae

\subsubsection{Gnathonemus tamandua}

Zoogeography: found in West Africa

Habitat Preference: fresh water; demersal.

Distinguishing Features and Morphology: the snout is prolonged into a long tubular structure with which it burrows into the bottom in search of worms and other organisms upon which it feeds. The chin has a small dermal appendage. Juveniles are light brownish-grey in colour and have two lighter vertical bands on the sides framing a darker bond. Adults become brownish-yellow, sometimes with a lighter vertical band in front of the dorsal and anal fins. 
Food and Feeding Habit: worms, small fish and insects; carnivorous

\section{Reproduction: oviparous}

Economic Importance: important for food and commercial fisheries.

Conservation Status: least concern.

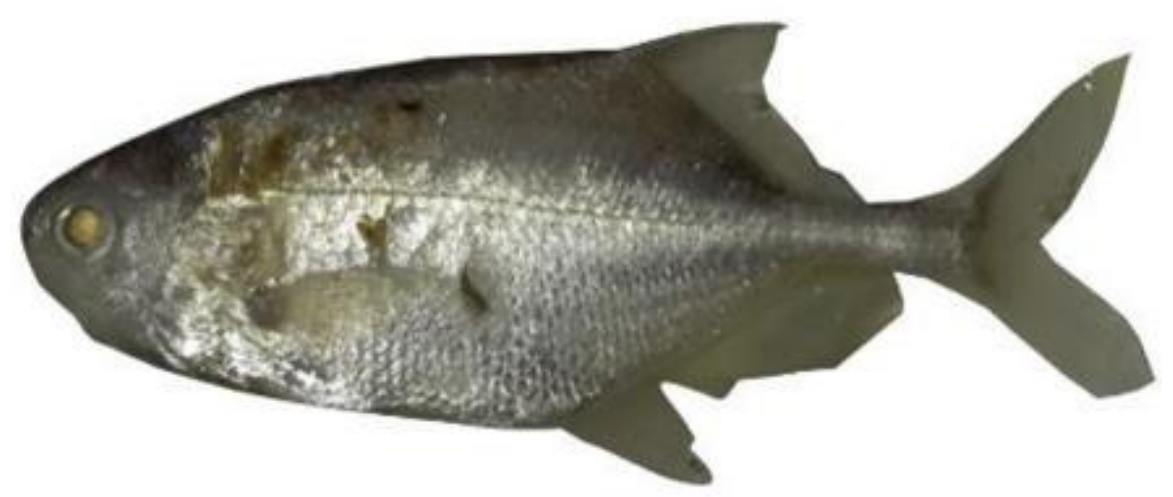

Family: Mormyridae

\subsubsection{Scientific Name: Petrocephalus bovei}

Zoogeography: Described from the Nile.

Widespread distributed in West Africa.

Habitat Preference: It inhibits swamps, rain forest, streams, and edges of rivers and lakes which provide vegetative protection.

Food and Feeding Habit: Chironomid larvae, Zooplankton, nematodes and detritus; Omnivore

\section{Reproduction: Oviparous}

Distinguishing Features and Morphology: Dorsal fin rays: 22-27; Anal fin rays: 30-36, Upper jaw with 9-13 teeth, Lower jaw 17-21 teeth. Maximum size: $100 \mathrm{~mm} \mathrm{SL}$

Economic Importance: They are consumed by many people, good for aquarium, can be used as baits for fishermen and animal feed

Conservation Status: Not Evaluated

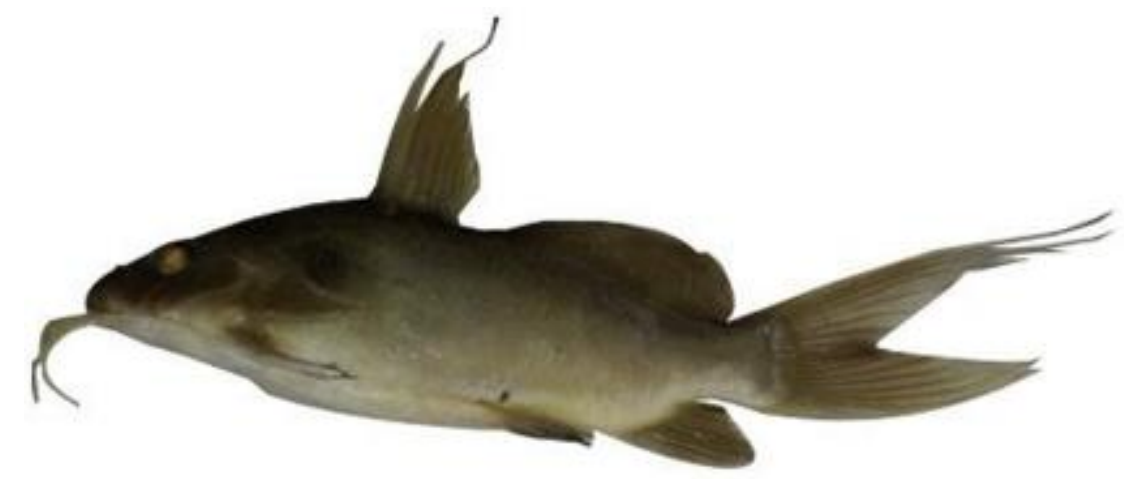

Family: Mochokidae 


\subsubsection{Scientific Name: Synodontis clarias}

Zoogeography: This species is patchily distributed from Senegal to Ethiopia, and along the entire length of the Nile. Northern Africa: It is present but rare in Lower Egyptian Nile and Lake Nasser (also known as Lake Nubia).

Northeast Africa: It occurs in the White Nile, Sudan, as well as the Blue Nile and Baro River, Ethiopia.

Western Africa: This species is known from basins of the Chad, Niger (plus the Benue), Senegal, Gambia and

Volta.

Habitat Preference: A bottom feeder, it feeds on chironomid larvae, plant remains and mud; freshwater

Distinguishing Features and Morphology: Dorsal spine with prolongation, upper lobe of tail elongated, Tail bright pink and Body grayish. They have stumpy body, scale less and smooth skin with formidable and serrated spin, an inferior mouth, a very number of branched barbell and adipose fin. The head is large and fully ossified.

Food and Feeding Habit: Feeds on insect larvae, mollusks, and detritus; Omnivore

Reproduction: Oviparous

Economic Importance: Fisheries: minor commercial; game fish:

Conservation Status: Least Concern.

\section{Conclusion}

This catalogue of fish species in Niger Delta Waters serves as a checklist of available fishes in both fresh and salt waters in Niger Delta that must be safeguarded from the effect of oil and gas industries and other anthropogenic activities prominent in the coastal water in this area. The catalogue will also serve as a reference material to research scholars, regulatory agencies and the government should any of these species go into extinction.

\section{Compliance with ethical standards}

\section{Acknowledgments}

We wish to acknowledge the efforts of Dr U. I. Daniel, whose inspiration led to this research work. We also convey our deep appreciation to Mr. Otufu of the Department of Animal and Environmental Biology laboratory, University of Port Harcourt, who helped in identification of the fishes.

\section{Conflict of interest}

There was no conflict of interest among the authors.

\section{Referenc es}

[1] World Bank. The Niger River Basin: A Vision for Sustainable Management. The World Geodetic System (WGS). 2005.

[2] Okonkwo CNP, Kumar L, Taylor S. The Niger Delta wetland ecosystem: What threatens it and why should we protect it? Afri. J. Environ. Sci. Technol. 2015; 9(5): 451-463.

[3] World Bank. Defining an environmental strategy for the Niger Delta. Nigeria: World Bank Industry and Energy Operations Division, West Central Africa Department. 1995.

[4] Uluocha N, Okeke I. Implications of wetlands degradation for water resources management: lessons from Nig. Geo. Journal. 2004; 61: 151.

[5] Ajonina G, Diamé A, Kairo J. Current status and conservation of mangroves in Africa: an overview. World Rainforest Mov Bull. 2008; 133. 
[6] Izah SC. Ecosystem of the Niger Delta region of Nigeria: Potentials and Threats. Biodiver. Int'l. J. 2018; 2(4): 338-345.

[7] Akachi O. Social Consequences of Environmental Change in the Niger Delta of Nigeria. J. Sustain. Develop. 2011; 4(2): 123-135.

[8] Etim E., Odoh R, Adams I, Lawal U. Water quality index for the assessment of water quality from different sources in the Niger Delta region of Nigeria. Front. Sci. 2013; 3(3): 89 - 95. 